WIDER Working Paper 2016/136

\title{
Cash transfers in Latin America
}

Effects on poverty and redistribution

Verónica Amarante ${ }^{1}$ and Martín Brun ${ }^{2}$

November 2016 
Abstract: In this paper, we present comparative evidence for eight Latin American countries regarding design and effects of cash transfers (CTs). On the basis of household survey data, we analyse their coverage, importance in household income, and effects on poverty reduction and income redistribution. We also present a static microsimulation to analyse the potential impacts of alternative programme designs including perfect targeting and higher budgets. Our results illustrate the wide variation of these interventions in terms of their design, coverage, and importance in household income. CTs account for a significant portion of household income in lower deciles. In spite of this, their effects in terms of reductions in the incidence, intensity, and severity of poverty are, in the best of cases, moderate and, although their progressivity is high, their redistributive impact is limited. These results are mainly explained by the meager resources involved. Even under perfect targeting, the budgets allocated to transfer programs in these countries would be insufficient to achieve full coverage in the lowest part of the income distribution.

Keywords: cash transfers, children, inequality, Latin America, poverty JEL classification: I38

Acknowledgments: The authors are grateful to Mirentxu Jiménez for excellent research assistance. An earlier version of this paper was presented at the United Nations University World Institute for Development Economics Research Symposium 'The Political Economy of Social Protection in Developing Countries', where we received valuable suggestions and comments from the participants.

${ }^{1}$ Director of Montevideo Office, ECLAC, Uruguay, corresponding author: veronica.amarante@cepal.org; 2Consultant at Montevideo Office, ECLAC, Uruguay.

This study has been prepared within the UNU-WIDER project on 'The political economy of social protection systems', which is part of a larger research project on 'The economics and politics of taxation and social protection'.

Copyright (C) UNU-WIDER 2016

Information and requests: publications@wider.unu.edu

ISSN 1798-7237 ISBN 978-92-9256-180-2

Typescript prepared by Ayesha Chari.

The United Nations University World Institute for Development Economics Research provides economic analysis and policy advice with the aim of promoting sustainable and equitable development. The Institute began operations in 1985 in Helsinki, Finland, as the first research and training centre of the United Nations University. Today it is a unique blend of think tank, research institute, and UN agency — providing a range of services from policy advice to governments as well as freely available original research.

The Institute is funded through income from an endowment fund with additional contributions to its work programme from Denmark, Finland, Sweden, and the United Kingdom.

Katajanokanlaituri 6 B, 00160 Helsinki, Finland

The views expressed in this paper are those of the author(s), and do not necessarily reflect the views of the Institute or the United Nations University, nor the programme/project donors. 
The provision of non-contributory cash transfers (CTs) is probably the social intervention that has received the most attention from scholars, policy makers, and international organizations since the mid-1990s in Latin America. These transfers were developed as a way to strengthen traditional social protection systems in the region, which were mainly tied to formal adscription to the labor market. Even if the pillar of social assistance did exist previously in the region, this new generation of transfers differentiated from more traditional ones in many aspects. Indeed, CTs mainly consist of the distribution of cash to poor households with children, with payments being conditioned on compliance with certain behaviors: school attendance for children, health controls for both children and pregnant women, and (in some cases) participation in nutrition and health training sessions for women, who are most often the recipients of the benefit. The main argument for the establishment of conditionalities (also called co-responsibilities) is their effectiveness to break the intergenerational transmission of poverty through their effect on human capital accumulation. Evidence for the effect of conditionalities is still limited, and their role remains a debated issue (see Standing, 2007; de Brauw and Hoddinott, 2008; Schady et al., 2008; Baird et al., 2011). As pointed out by Bosch and Manacorda (2012), although conditionalities are almost universal features of the design of CT programs in the region, some programs are de facto unconditional. In formal terms, all the programs considered in this paper include conditionalities (see details in Appendix B), although the level of enforcement of these conditionalities may differ.

Other distinctive features of CTs are their strict eligibility criteria-most of them being based on proxy means testing of income-and the implementation of credible impact evaluations, which have contributed to expanding our knowledge about the impacts of these programs. ${ }^{1}$ Last but not least, one attractive feature of CTs is their low opportunity cost in terms of alternative public investments, as they involve a relatively low budget compared with other social policies.

These innovative CTs have generated profuse literature, particularly focused on their evaluation (for reviews of this literature, see Bouillon and Tejerina, 2006; Fiszbein and Schady, 2009; Gaarder et al., 2010; Cecchini and Martínez, 2011; Saavedra and Garcia, 2012; Manley et al., 2013). In general, there is an agreement about their positive impact in terms of improving living standards at the bottom of the distribution, and reducing poverty and inequality. Most evidence on these issues comes from specific country studies, as comparative analysis is relatively scarce.

The different CT programs have some common features but also differ in very specific factors. Among important aspects, they differ in the way they are related to the institutional and legal framework, in the existence or not of complementary programs, in the links of the transfer program with the rest of the social protection system, in the funding conditions, in the enforcement of conditionalities, in the recertification and exit strategies, and in the existence and type of indexation mechanism of the benefits. At a more basic level, they differ in the amount and structure of transfers and in their coverage. Given this, comparative evidence is useful and necessary. In this paper, we provide evidence of the coverage of CTs in eight Latin American countries, as well as of their importance in household income and their effects on poverty reduction and income redistribution. Our analysis is based on recent household survey data.

\footnotetext{
${ }^{1}$ The pioneering program was Progresa-Oportunidades in Mexico, which was created in 1997 and designed to allow for a randomized impact evaluation on a wide scope of outcome variables.
} 
Besides considering the actual effects, we develop a static microsimulation exercise to analyze the potential impacts of alternative program designs.

The rest of the article is organized as follows. Section 2 describes the main characteristics of the cash transfer (CT) programs under consideration, and reviews existing literature on the impact of CTs on poverty and inequality. Section 3 is devoted to the discussion of methodological issues. Section 4 presents our results related to the coverage and targeting of the programs, and the importance of the transfers on household income. Section 5 discusses their direct effects on poverty and inequality reduction, as well as their effectiveness. Section 6 presents the results of arithmetical microsimulations of alternative designs, and finally some concluding comments are presented in Section 7.

\section{Non-contributive CTs to households with children in selected countries}

Given the well-documented long-term effects of deprivation during childhood, the idea of giving money to poor households with children to foster human capital investment has gained many adepts, and even been described as a 'quiet' revolution in development thinking (Barrientos and Hulme, 2008). In Latin America, the expansion of these interventions since the mid-1990s has implied that today around $20 \%$ of the population live in households covered by these transfers (see ECLAC, 2015).

In this paper, we provide an in-depth analysis of eight Latin American countries, considering poverty impacts as well as redistributive effects. We also provide evidence for the potential impact of alternative transfer designs. The countries included in this study were selected in order to guarantee the correct identification of beneficiary households and the amount of transfer, based on household survey data. ${ }^{2}$ The main characteristics of the programs are detailed in Appendix B.

The importance of these programs in terms of their budget for the years considered in this paper (2011-13), are presented in Table 1. No country among the ones considered in this paper assigns more than $0.5 \%$ of gross domestic product (GDP) to these transfers, except for the case of Ecuador where the figure reaches $1.12 \%$ of GDP. ${ }^{3}$

The amount of transfer varies significantly across countries. A calculation based on household survey data, and considering that all people living in a household that receives CTs are beneficiaries, indicates that the annual transfer per person in Uruguay is four times that in Peru and more than ten times that in Bolivia [in purchasing power parity (PPP) USD] (Figure 1). This is a first warning about the heterogeneity of these interventions and of the kind of income security that they may provide.

\footnotetext{
${ }^{2}$ This implies that we only consider countries for which the household survey provides information about whether the household is a beneficiary, and where information about the amount of the transfer is available or can be imputed without ambiguity. Consequently, Argentina and Brazil, where the beneficiaries have to be identified indirectly through the consideration of perceived amounts of specific non-labor incomes, and Mexico, where participation in the program can be deducted through the reception of transfer, were not included in our analysis (see Appendix C).

${ }^{3}$ The budget of these programs for the latest available year is presented in Appendix Table A1. The main difference with Table 1 corresponds to Ecuador, whose budget drop significantly in consequence of a decreased coverage due to the application of stricter targeting rules. In the case of Chile, we consider only the cash transfer received by poor families with children; other related programs and benefits are not included in the figures presented in Table 1.
} 
Table 1: Coverage and budget of selected child transfer programs in Latin America

\begin{tabular}{llll}
\hline Country & Program & Budget (\% GDP) & Year \\
\hline Bolivia & Bono Juancito Pinto & 0.23 & 2011 \\
Chile & Chile Solidario & 0.09 & 2011 \\
Costa Rica & Avancemos & 0.20 & 2013 \\
Ecuador & Bono de Desarrollo Humano & 1.12 & 2013 \\
Panama & Red de Oportunidades & 0.14 & 2011 \\
Paraguay & Tekopora & 0.14 & 2013 \\
Peru & Juntos & 0.17 & 2013 \\
Uruguay & Asignaciones Familiares & 0.37 & 2013 \\
\hline
\end{tabular}

Source: ECLAC (2016).

Figure 1: Annual cash transfer (CT) per person (c.2013)

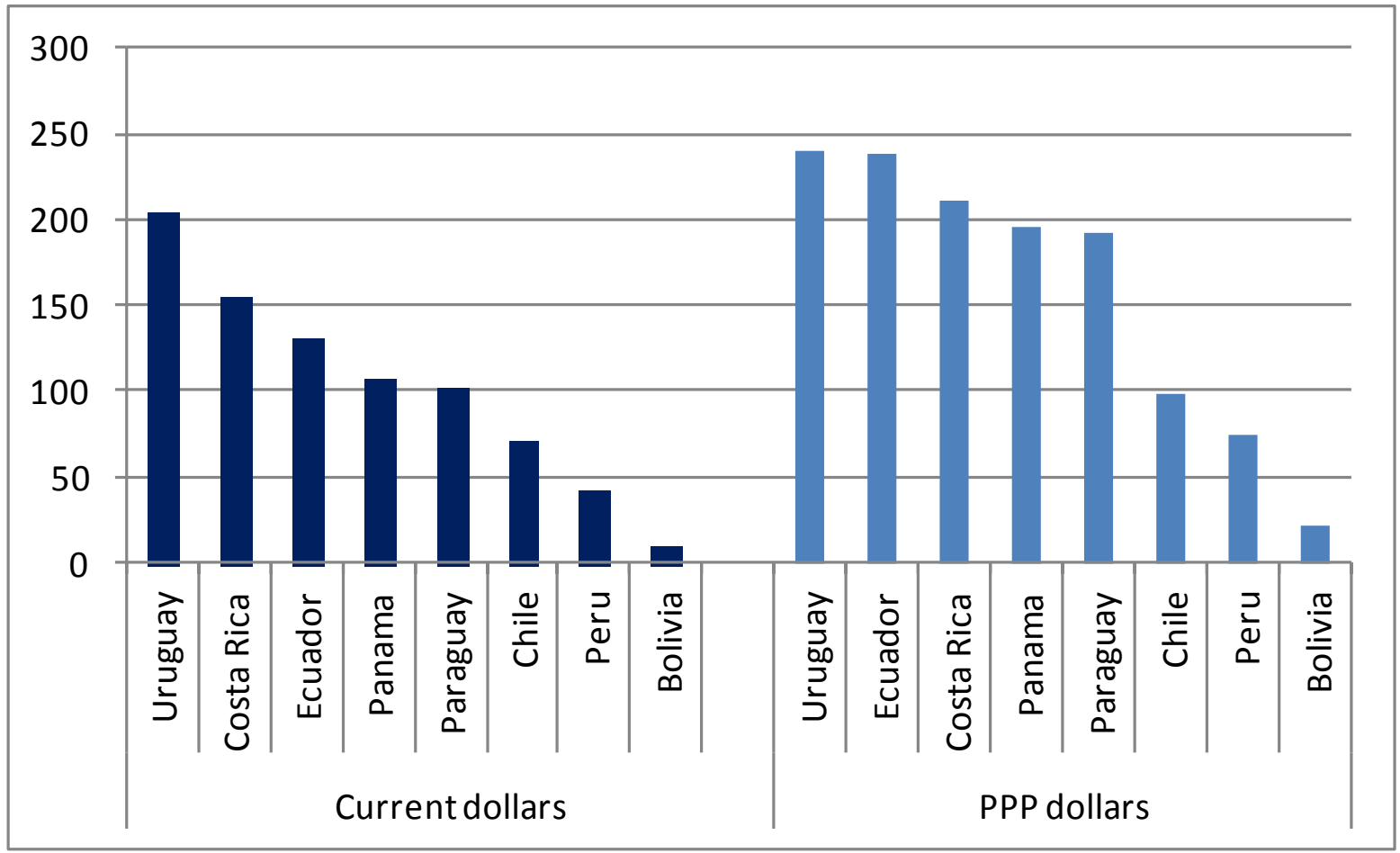

Source: Authors' illustration based on household surveys and World Bank indicators.

As stated before, the achievements of CTs in terms of increasing the demand for education and health services has been widely discussed. Various studies also document the direct impact of CTs on poverty and inequality reduction (Soares et al., 2007, 2009; ECLAC, 2010). Evidence from these different studies suggests a high degree of cross-country variation, although comparative studies considering different countries are scarce. Among these scarce comparative studies, Cecchini and Madariaga (2011) consider the importance of CTs in comparison with the poverty and indigence lines in each country, considering the thresholds set out by the Economic Commission for Latin America and the Caribbean (ECLAC) to define poverty. They show that, in rural areas, the amount of transfer averages $12 \%$ of the indigence line and $7 \%$ of the poverty line, whereas in urban areas they are equivalent to $11 \%$ and $5 \%$, respectively. The comparison of the amount of transfer with the monthly resource deficit shows diverse situations by country. As a regional average, minimum transfer amounts represent $13.5 \%$ of the mean monthly resource deficit of the poor population in urban areas and $17 \%$ in rural areas. A recent paper by Stampini and Tornarolli (2012) studies the ability of conditional CTs (CCTs) to reach the poor in Latin American countries, by providing standardized measures of poverty, coverage, and leakage for 13 countries. To identify poor households, they use an international poverty line set at USD 2.5 per capita per day for extreme poverty and USD 4 per capita per day for poverty. They find that the 
poverty headcount index would be on average 13\% higher (with variations ranging from 1\% in Paraguay to $59 \%$ in Uruguay) if CTs did not exist. They report a greater impact in terms of poverty gap and squared poverty gap. They also find that, over the decade, the implementation of CCTs in the region has been characterized by growing levels of leakage.

\section{Methodological aspects}

The analysis presented in this article is based on household surveys for eight Latin American countries. Data correspond to circa 2013; details on the programs considered and the identification procedures are presented in Appendix Table A2. We consider countries whose household survey directly asks interviewed households whether they are beneficiaries of the programs, and do not include countries where identification of beneficiaries is possible through indirect questions. This is the case, for example, of Argentina and Brazil, where beneficiaries can be indirectly identified through the amount of specific components of non-labor income (see Gasparini and Cruces, 2010), or Mexico, where the survey asks whether the household receives a transfer from the government social assistance program Oportunidades (but not whether it is a beneficiary). The decision not to include these countries was taken in order to avoid any strategy that may lead to identification errors. Additionally, we do not include Colombia in our analysis as the latest available information on CT programs refers to 2008.

We provide indicators of the incidence of poverty, the poverty gap, and the squared poverty gap, with and without transfers, based on reported household income. We also report inequality indexes and analyze redistributive impacts. When the value of benefits is reported in the survey, we use this information for this exercise. Otherwise, we use official information on the amount of transfers.

Poverty is identified using ECLAC's poverty and indigence lines. These poverty lines, expressed in national currency, reflect a calculation of the cost of a basket of basic goods and services, using the cost of basic needs method. The cost of a basic food basket that covers a person's nutritional needs was estimated for each country and geographical area, taking into account consumption habits, the actual availability of foodstuffs, and their relative prices, as well as the price differences between metropolitan areas, other urban areas, and rural areas. This defines the indigence line. The poverty line is defined by adding to the indigence line an estimate of the resources needed by a household to satisfy its basic non-nutritional needs. This estimated amount is the result of multiplying the indigence line by a constant factor of 2 for urban areas and 1.75 for rural areas at the moment data were collected. These data on the structure of household consumption of foodstuffs and other goods and services come from national expenditure surveys. The value of poverty and indigence lines is updated using cumulative variations in the consumer price index (see ECLAC, 2013: 54). Additionally, poverty is also estimated using World Bank's poverty of USD 3.10 at 2011 PPP conversion factor. As expected, results differ significantly in absolute levels, as poverty is lower when measured with this lower threshold, but the main findings remain. Statistical results are presented in Appendix A. ${ }^{5}$

\footnotetext{
${ }^{4}$ The same variation was applied to poverty and indigence lines until December 2006. From then on, the indigence line is adjusted to reflect changes in prices of food, whereas non-food spending is adjusted to reflect changes in that component of the consumer price index.

${ }^{5}$ When poverty is calculated using ECLAC thresholds, household income is corrected to account for lack of response (wage earners, self-employed, and retirees) and for probable biases from underreporting (ECLAC, 2010).
} 
We also provide evidence from microsimulation exercises that consider alternative program designs. We consider three different scenarios. In the first one, we assume perfect targeting of the actual budgets of CT programs. In the second scenario, program budgets are doubled and resources are targeted toward actual beneficiaries. In the third scenario, program budgets are doubled but resources are targeted toward poorer households.

Our simple arithmetical microsimulations may overestimate the impacts of transfers on poverty and inequality, as they assume that household behavior in terms of labor force participation would not change in case the transfer did not exist. Although this is a strong assumption, the available evidence does not detect, in general terms, unintended effects of CT programs on labor supply at the extensive margin, although reductions in hours of work or substitution away from formal to informal employment were detected in some cases (for a survey, see Bosch and Manacorda, 2012). ${ }^{6}$

\section{$4 \quad$ Beneficiaries of CCTs and importance of transfer}

With the expansion of CTs in the region, a significant percentage of the population is now covered by these programs, although there are important differences by countries. According to household surveys data, in Bolivia, half of the population lives in households that receive CTs, whereas in Chile and Paraguay coverage is $<4 \%$ of the population (Table 2). In all cases, the percentage of beneficiaries decreases with income, with high levels of variation in terms of coverage for poorer households. Bolivia, Ecuador, and Uruguay (the countries with the highest coverage in our sample) exhibit a higher inclusion of poorer individuals, whereas in Costa Rica and Paraguay there is a significant under-coverage among the first decile.

Table 2: Coverage of CCT programs (as \% of total population) (c.2013).

\begin{tabular}{lllllllll}
\hline & Bolivia & Chile & Costa Rica & Ecuador & Panama & Paraguay & Peru & Uruguay \\
\hline D1 & 75.7 & 8.1 & 17.6 & 54.6 & 35.7 & 13.6 & 41.1 & 77.0 \\
D2 & 63.6 & 5.6 & 23.1 & 52.1 & 26.4 & 7.2 & 26.7 & 59.3 \\
D3 & 63.1 & 4.7 & 17.1 & 41.2 & 13.6 & 6.4 & 16.5 & 40.8 \\
D4 & 64.1 & 3.3 & 13.7 & 31.7 & 6.5 & 4.0 & 9.3 & 23.3 \\
D5 & 58.3 & 2.8 & 12.5 & 29.6 & 4.0 & 2.7 & 5.4 & 12.7 \\
D6 & 51.4 & 2.6 & 11.1 & 21.5 & 2.0 & 3.0 & 2.1 & 7.9 \\
D7 & 46.4 & 2.0 & 5.2 & 14.7 & 1.3 & 0.6 & 1.3 & 3.7 \\
D8 & 38.9 & 1.2 & 1.6 & 9.4 & 0.4 & 0.5 & 0.8 & 1.6 \\
D9 & 31.6 & 1.4 & 1.0 & 3.0 & 0.1 & 0.0 & 0.2 & 0.6 \\
D10 & 19.9 & 0.8 & 0.4 & 0.9 & 0.2 & 0.1 & 0.0 & 0.2 \\
Total & 51.3 & 3.3 & 10.3 & 26.0 & 9.0 & 3.8 & 10.3 & 22.7 \\
\hline
\end{tabular}

Source: Authors' compilation based on household surveys.

As expected, higher coverage implies higher leakage. Whereas the first decile captures a significant proportion of total beneficiaries in Panama, Peru, Paraguay, and Uruguay in countries with higher coverage, such as Bolivia and Ecuador, the five upper deciles capture 37\% and 26\% of total beneficiaries, respectively (Table 3 ).

This is needed in order to keep consistency with ECLAC poverty lines. To calculate distributional impacts or poverty using World Bank thresholds, income vectors are only corrected to account for lack of response (and not for potential underreporting).

${ }^{6}$ Some specific studies of Latin America experiences include Parker and Skoufias (2000), Galasso (2006), and Maluccio (2007), Skoufias and di Maro (2008), and Alzúa et al. (2010). 
Table 3: Distribution of beneficiaries by income decile (c.2013)

\begin{tabular}{lllllllll}
\hline & Bolivia & Chile & Costa Rica & Ecuador & Panama & Paraguay & Peru & Uruguay \\
\hline D1 & 14.8 & 24.8 & 17.0 & 23.3 & 39.6 & 35.7 & 39.7 & 33.9 \\
D2 & 12.4 & 17.2 & 22.3 & 18.0 & 29.2 & 18.8 & 25.8 & 26.1 \\
D3 & 12.3 & 14.4 & 16.6 & 16.3 & 15.1 & 16.7 & 16.0 & 18.0 \\
D4 & 12.5 & 10.2 & 13.2 & 12.0 & 7.2 & 10.5 & 9.0 & 10.3 \\
D5 & 11.4 & 8.6 & 12.2 & 11.2 & 4.4 & 7.2 & 5.2 & 5.6 \\
D6 & 10.0 & 8.0 & 10.7 & 8.3 & 2.2 & 7.9 & 2.1 & 3.5 \\
D7 & 9.0 & 6.2 & 5.1 & 5.9 & 1.5 & 1.6 & 1.3 & 1.6 \\
D8 & 7.6 & 3.8 & 1.6 & 3.5 & 0.5 & 1.4 & 0.7 & 0.7 \\
D9 & 6.1 & 4.4 & 0.9 & 1.1 & 0.1 & 0.0 & 0.2 & 0.3 \\
D10 & 3.9 & 2.4 & 0.4 & 0.4 & 0.2 & 0.2 & 0.0 & 0.1 \\
Total & 100.0 & 100.0 & 100.0 & 100.0 & 100.0 & 100.0 & 100.0 & 100.0 \\
\hline
\end{tabular}

Source: Authors' compilation based on household surveys.

CTs constitute an important source of income among households in the lower deciles, although their importance is variable by country (Table 4). Transfers represent a higher proportion of total household income in Ecuador and Panama and a lesser extent in Paraguay and Costa Rica (see Table 4 and Appendix Figure A1). If we restrict the analysis to the first decile, around one-third of total household income is explained by these CTs in Costa Rica, Ecuador, and Panama. Similar information related to the importance of transfers is obtained when we compare the amount of transfer in per capita with the poverty and indigence lines (see Appendix Figures A2 and A3). In all countries, CTs imply a significant improvement in terms of available resources for households in the bottom of the income distribution, especially in the first and-depending on the country-second deciles.

Table 4: Amount of transfer as a percentage of household income of beneficiary households

\begin{tabular}{lllllllll}
\hline & Bolivia & Chile & Costa Rica & Ecuador & Panama & Paraguay & Peru & Uruguay \\
\hline D1 & 7.8 & 8.1 & 29.7 & 33.6 & 31.3 & 21.7 & 9.7 & 11.0 \\
D2 & 2.4 & 3.4 & 11.1 & 19.4 & 17.0 & 12.5 & 5.7 & 6.0 \\
D3 & 1.5 & 2.9 & 8.2 & 15.8 & 12.3 & 9.5 & 3.9 & 4.6 \\
D4 & 1.1 & 2.5 & 7.2 & 12.6 & 10.5 & 8.8 & 3.2 & 3.8 \\
D5 & 0.8 & 2.1 & 5.4 & 10.4 & 8.0 & 6.3 & 2.6 & 3.2 \\
D6 & 0.6 & 2.0 & 4.8 & 9.5 & 5.3 & 3.8 & 2.1 & 2.6 \\
D7 & 0.5 & 1.7 & 3.3 & 7.1 & 5.2 & 5.2 & 1.9 & 2.2 \\
D8 & 0.4 & 1.4 & 3.0 & 5.7 & 3.9 & 5.7 & 1.4 & 2.0 \\
D9 & 0.3 & 0.9 & 1.7 & 3.8 & 5.0 & $=-$ & 0.9 & 1.7 \\
D10 & 0.2 & 0.6 & 0.8 & 2.8 & 1.6 & 2.9 & 0.1 & 0.8 \\
Total & 1.9 & 3.6 & 11.0 & 17.5 & 19.5 & 13.2 & 6.3 & 6.6 \\
\hline
\end{tabular}

Source: Authors' compilation based on household surveys.

\section{$5 \quad$ Impacts of CTs on poverty and inequality}

By providing a new source of income to households, these CTs can help to reduce poverty and inequality. Regarding the effects on poverty, Table 5 shows the three poverty indicators based on the Foster-Greer-Thorbecke (FGT) indices (i.e., incidence "FGT 0," poverty gap "FGT 1," and squared poverty gap "FGT 2") obtained from the original income reported by households, and computed assuming that CTs did not exist. The measure of poverty is calculated based on the poverty lines of ECLAC. 
Table 5: Direct effect of cash transfers (CTs) on poverty (\% population) (c.2013)

\begin{tabular}{lllllll}
\hline & $\begin{array}{l}\text { FGT 0 (with } \\
\text { CCTs) }\end{array}$ & $\begin{array}{l}\text { FGT 0 (without } \\
\text { CCTs) }\end{array}$ & $\begin{array}{l}\text { FGT 1 (with } \\
\text { CCTs) }\end{array}$ & $\begin{array}{l}\text { FGT 1 (without } \\
\text { CCTs) }\end{array}$ & $\begin{array}{l}\text { FGT 2 (with } \\
\text { CCTs) }\end{array}$ & $\begin{array}{l}\text { FGT 2 (without } \\
\text { CCTs) }\end{array}$ \\
\hline Bolivia & 36.0 & 36.2 & 15.2 & 15.5 & 9.1 & 9.3 \\
Chile & 7.8 & 7.8 & 2.5 & 2.5 & 1.3 & 1.3 \\
Costa Rica & 17.7 & 18.3 & 6.9 & 7.2 & 4.0 & 4.3 \\
Ecuador & 33.6 & 36.0 & 11.7 & 13.6 & 5.7 & 7.3 \\
Panama & 23.6 & 24.1 & 9.7 & 10.3 & 5.5 & 6.1 \\
Paraguay & 40.5 & 40.7 & 16.5 & 16.7 & 9.2 & 9.4 \\
Peru & 24.0 & 24.3 & 8.2 & 8.4 & 3.9 & 4.1 \\
Uruguay & 5.6 & 6.6 & 1.5 & 1.9 & 0.6 & 0.8 \\
\hline
\end{tabular}

Source: Authors' compilation based on household surveys.

The change in poverty indicators due to CTs, in absolute terms, is limited in all countries, with the exception of Ecuador (Table 5). This country exhibits the highest decrease in the incidence of poverty as a consequence of transfers ( 2.4 points), followed by Uruguay (1 point). Although the absolute changes in poverty indicators are moderate (lower than 1 point in all cases, with the exceptions of Ecuador and Uruguay), the change in percentages is higher, as small changes in countries with low poverty (such as Uruguay) imply high variations (see Figure 2). Consequently, we can say that CTs imply a reduction of $15 \%$ of poverty in Uruguay, $7 \%$ in Ecuador, and 3\% in Costa Rica. Also, percentage variations in poverty intensity and severity tend to be higher than changes in incidence. The general picture is that reductions in incidence, intensity, and severity of poverty are moderate in absolute terms, with important variations between countries and greater achievements in Ecuador and Uruguay. When poverty is calculated using the World Bank poverty line of USD 3.10, the incidence is lower in all countries, and the effects are smaller (see Appendix Table A3 and Appendix Figure A3). Nevertheless, the ordering of countries in terms of the importance of effects is similar.

Figure 2: Absolute (a) and relative (b) change in poverty indicators induced by CTs

(a)

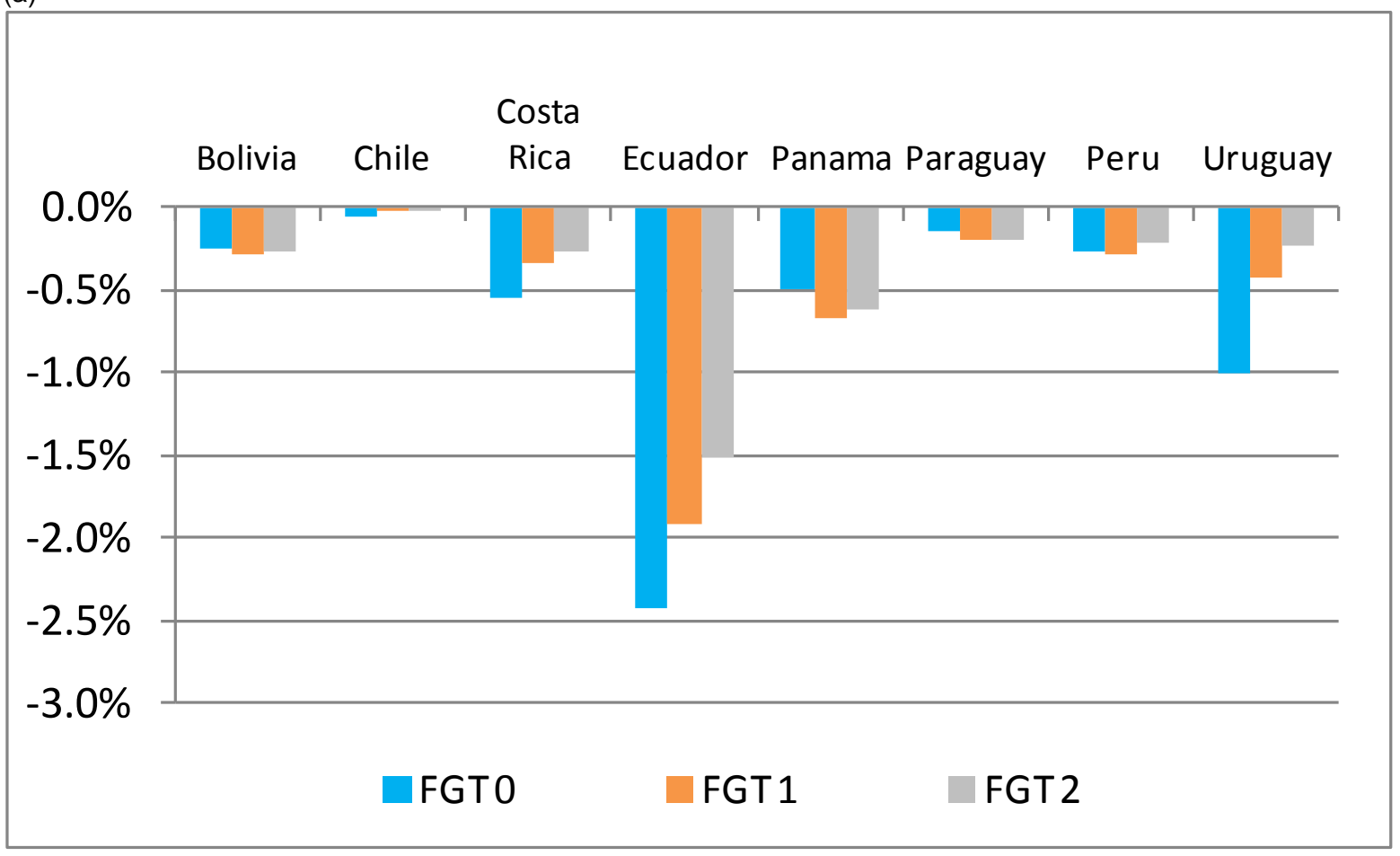


(b)

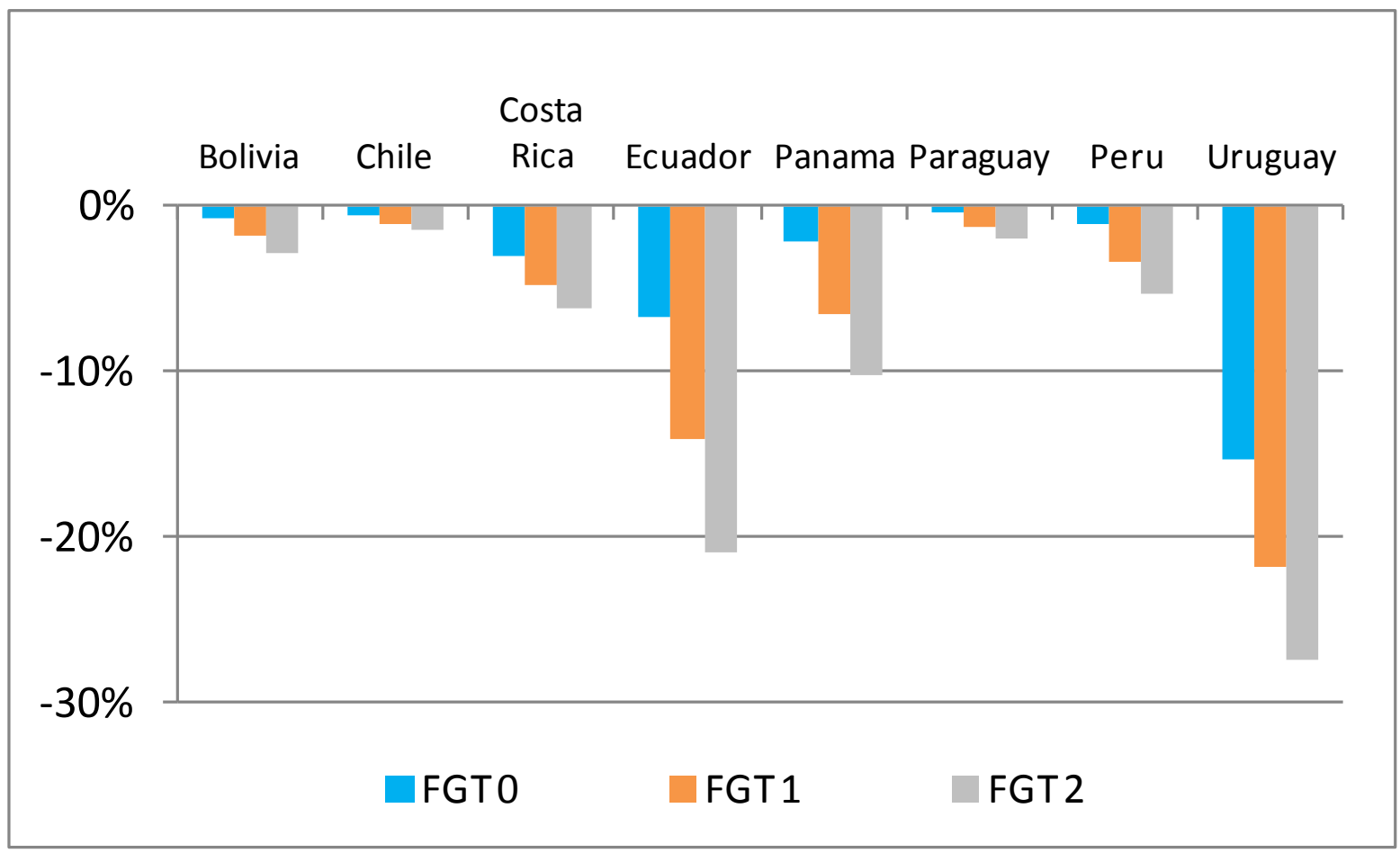

Source: Authors' illustration based on household surveys.

In order to study the impact of CCTs on inequality, we computed indicators of progressivity and redistributive impact. A transfer is considered progressive if its amount decreases with the household income. A typical way to measure progressivity is to use the Kakwani index: ${ }^{7}$ a positive value of the index indicates progressivity and major values indicate major progressivity. In order to measure the redistributive impact of a transfer, it is common to use the ReynoldsSmolensky index, which corresponds to the difference in the Gini index before and after the transfer. The total redistributive effect of a transfer depends positively on its progressivity and its mean value, whereas it depends negatively on the potential reordering of households due to the transfer. This implies that transfers may be highly progressive, like in Panama, Paraguay, Peru, and Uruguay, and still have a low redistributive impact. Indeed, in these cases, the variation between the Gini index before and after the transfers is lower than half a percentage point, even when the transfers are highly progressive. This is mainly explained by the low value of average benefits; that is, the relatively low level of the resources involved. The program of Ecuador is the one that exhibits the highest redistributive impact; it is also the one that involves the highest level of resources (Figure 3). So even if programs are very well targeted and exhibit high progressivity, their impacts in terms of redistribution depend on the share of total household income that they represent. It is interesting to note that a similar exercise carried out for Brazil and Mexico, the "stars" among these kind of interventions, found that similar CTs in these countries were able to reduce the Gini inequality by around 2.7 points (Soares et al., 2007).

\footnotetext{
${ }^{7}$ The Kakwani index is defined as double the area between the concentration curve corresponding to the transfer and the Lorenz curve corresponding to the initial income distribution. In the case of transfers, we compute it as the difference between the Gini index corresponding to the initial income minus the concentration index corresponding to the benefits induced by the transfer (see Gasparini et al., 2013).
} 
Figure 3: Progressivity and redistributive impact of non-contributory CTs

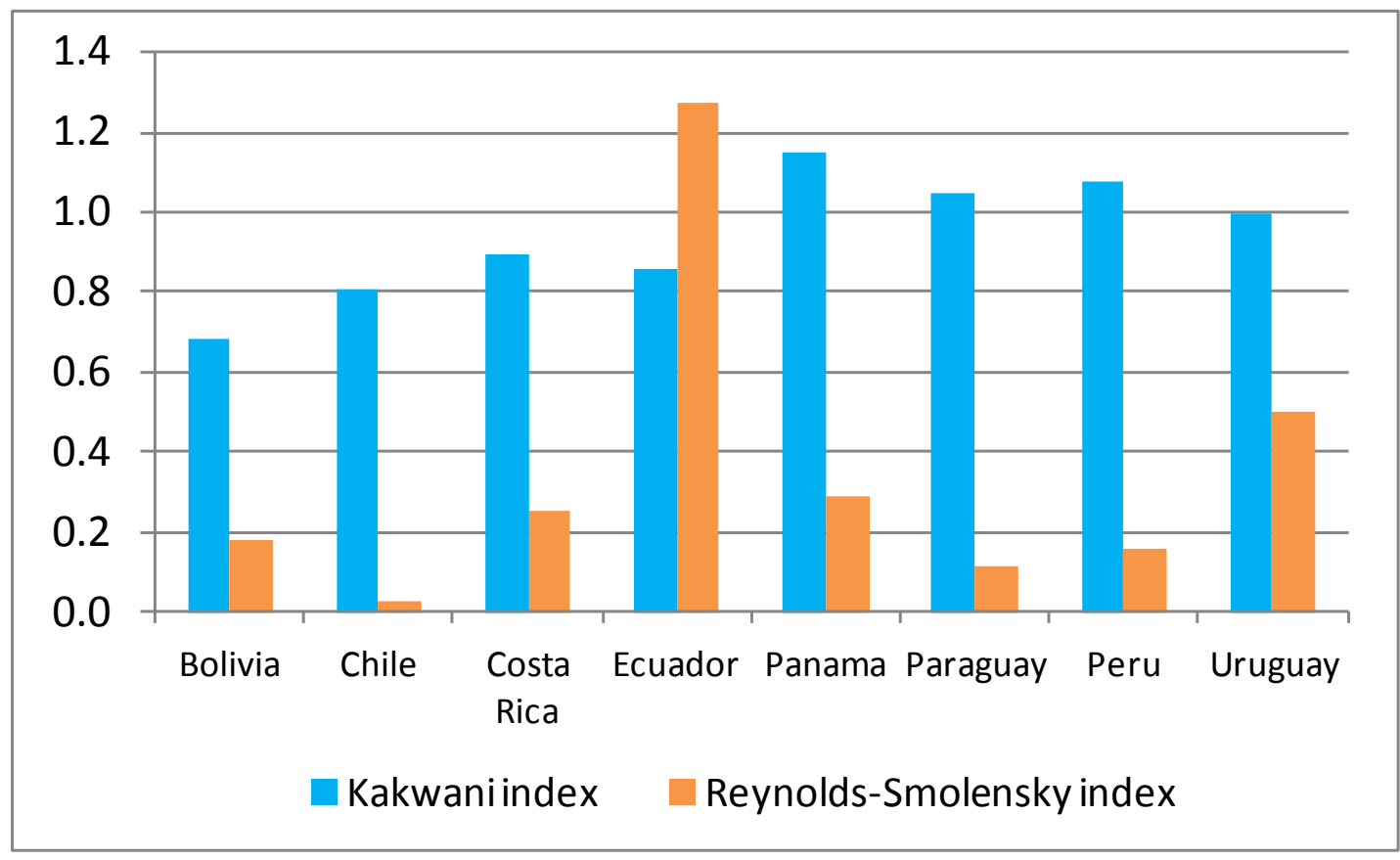

Source: Authors' illustration based on household surveys.

The progressivity of transfers can also be illustrated through the concentration curves, which show similar results to the Kakwani index (Figure 4). All programs help to reduce inequality: Panama, Uruguay, and Peru are the most progressive programs (the concentration curves are more distant from the $45^{\circ}$ line); Paraguay, Ecuador, and Costa Rica are in an intermediate range; and Chile and Bolivia are the least progressive.

Figure 4: Concentration curves of CTs

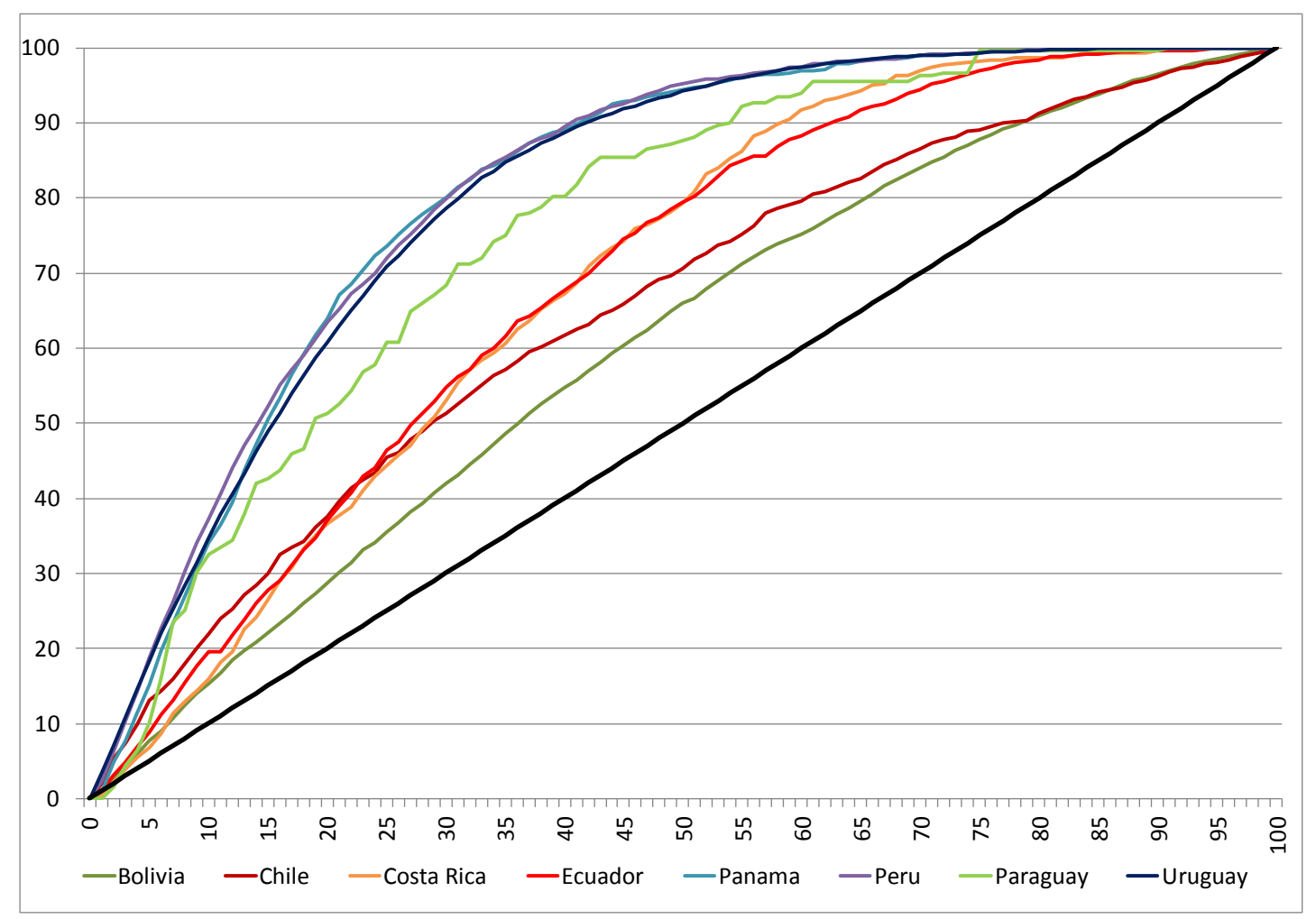

Source: Authors' illustration based on household surveys. 
We compared the efficiency of the CT programs in different countries in terms of their capacity for reducing poverty and inequality by dollar invested. Figures $5 \mathrm{a}$ and $5 \mathrm{~b}$ show the achievements in points of reduction of poverty incidence and inequality, respectively, by 1,000 million dollars invested (current and PPP). The ordering of countries is similar in terms of their effectiveness to reduce both poverty and inequality (current and PPP dollars). Panama is the best performer, followed by Costa Rica and Uruguay, whereas Peru and Chile present lower indicators in both cases.

Figure 5: Reduction in poverty (a) and inequality (b) by dollar invested

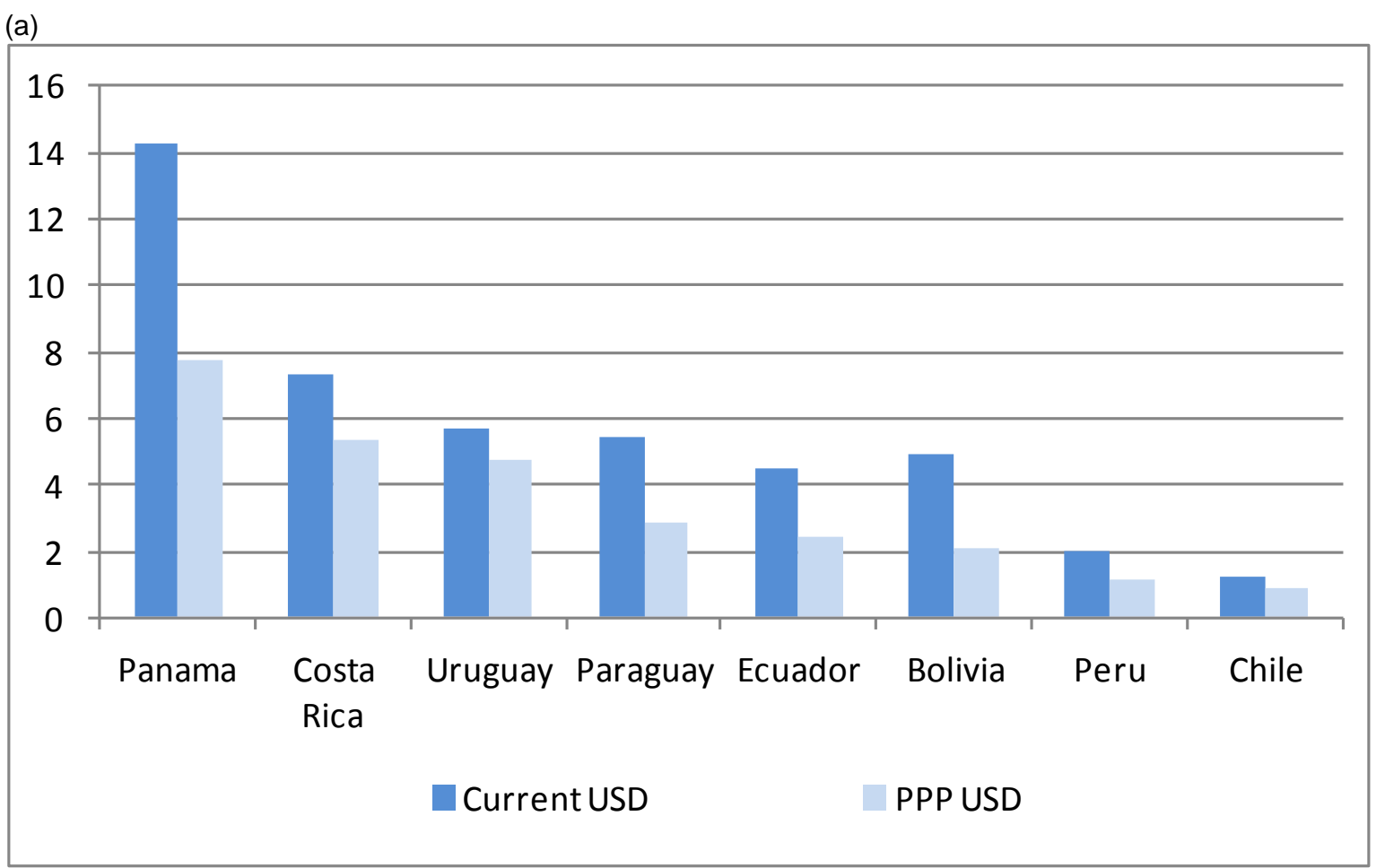

(b)

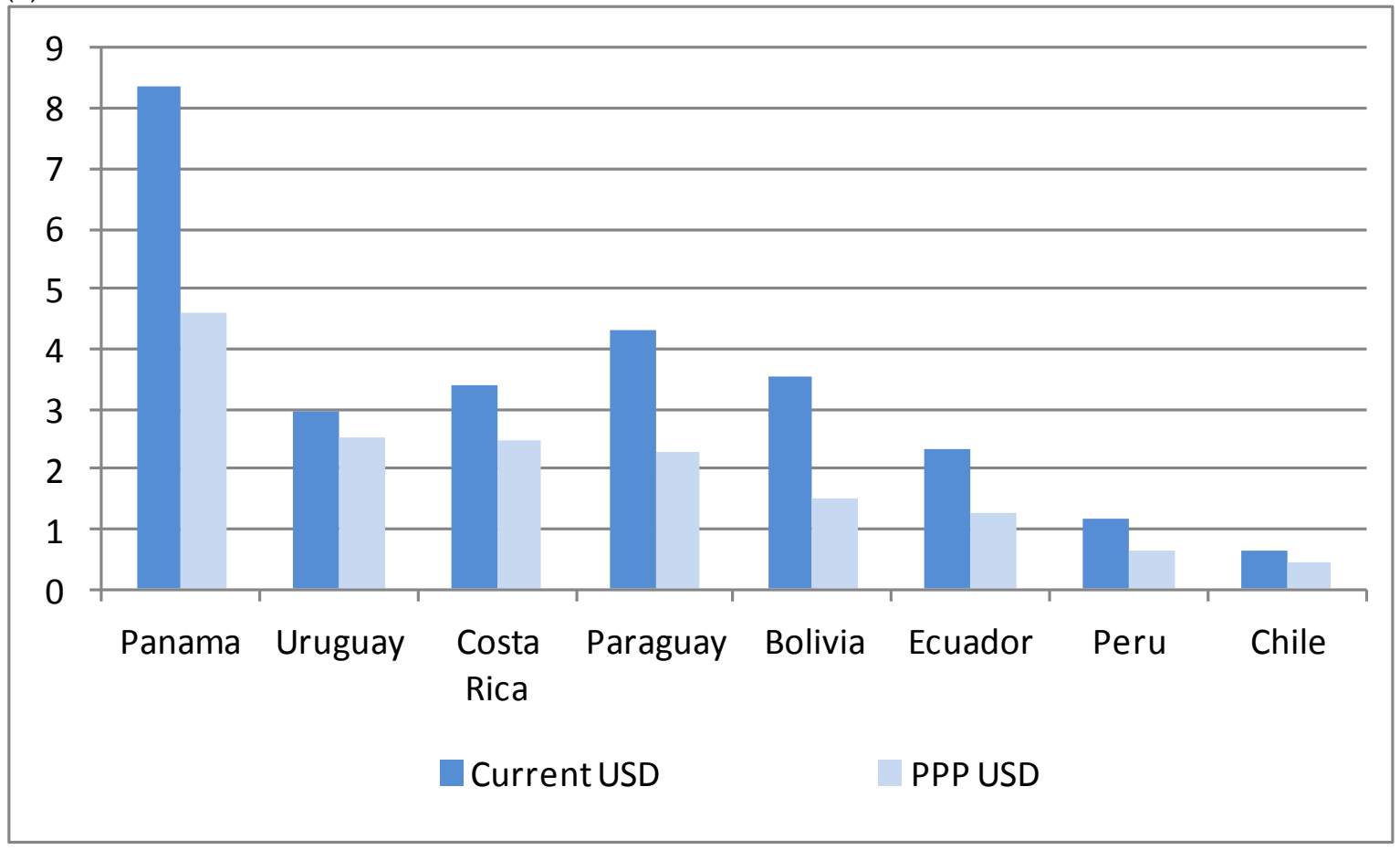

Source: Authors' illustration based on household surveys and ECLAC (2016). 


\section{$6 \quad$ Alternative designs of CTs: effects on poverty and inequality}

The effects of transfers on poverty and inequality are a result of the targeting implementation and the amount of transfer, as discussed before. To disentangle the potential role of these two channels, we develop static microsimulations and consider the impact of three alternative program designs, as follows: in scenario 1, the program budget is unchanged, but the program is perfectly targeted toward poorer households with children. In scenario 2 , the program budget is doubled, but beneficiaries remain the same. Finally, scenario 3 presents a combination of scenarios 1 and 2. In this section, we present the results obtained from these three alternative designs, comparing with the situation derived from the present design.

A first analysis consists of looking at the distribution of beneficiaries under different scenarios. It must be stressed that this distribution does not change under scenario 2 with respect to the original program (only the budget is doubled), but changes with respect to the original in scenarios 1 and 3, which assume perfect targeting. In these cases, the distribution of beneficiaries coincides, but the scenarios imply different budgets. Under perfect targeting of cash programs (scenarios 1 and 3), transfers are provided to the poorest households with children. Moreover, transfers are provided in an ordered manner, starting at the households from the lowest percentiles with the greater number of children, until each country's budget runs out. By construction, the excluded households among the poorest correspond to those where there are no children. The result is that no household belonging to the two upper deciles perceives the CT in any country (Table 6). Moreover, only in Bolivia, Ecuador, and Uruguay transfers are given to households out of the first two deciles. It is worth noting that countries such as Chile, Panama, and Paraguay end up allocating their entire budget solely in the first decile.

Table 6: Distribution of beneficiaries by income decile under different scenarios

\begin{tabular}{|c|c|c|c|c|c|c|c|c|c|c|c|c|}
\hline & & D1 & D2 & D3 & D4 & D5 & D6 & D7 & D8 & D9 & D10 & Total \\
\hline \multirow[t]{2}{*}{ Bolivia } & $\begin{array}{l}\text { Original and } \\
\text { scenario } 2\end{array}$ & 15 & 12 & 12 & 12 & 11 & 10 & 9 & 8 & 6 & 4 & 100 \\
\hline & Scenarios 1 and 3 & 16 & 15 & 14 & 15 & 14 & 12 & 13 & 1 & 0 & 0 & 100 \\
\hline \multirow[t]{2}{*}{ Chile } & $\begin{array}{l}\text { Original and } \\
\text { scenario } 2\end{array}$ & 25 & 17 & 14 & 10 & 9 & 8 & 6 & 4 & 4 & 2 & 100 \\
\hline & Scenarios 1 and 3 & 100 & 0 & 0 & 0 & 0 & 0 & 0 & 0 & 0 & 0 & 100 \\
\hline \multirow[t]{2}{*}{ Costa Rica } & $\begin{array}{l}\text { Original and } \\
\text { scenario } 2\end{array}$ & 17 & 22 & 17 & 13 & 12 & 11 & 5 & 2 & 1 & 0 & 100 \\
\hline & Scenarios 1 and 3 & 72 & 28 & 0 & 0 & 0 & 0 & 0 & 0 & 0 & 0 & 100 \\
\hline \multirow[t]{2}{*}{ Ecuador } & $\begin{array}{l}\text { Original and } \\
\text { scenario } 2\end{array}$ & 23 & 18 & 16 & 12 & 11 & 8 & 6 & 3 & 1 & 0 & 100 \\
\hline & Scenarios 1 and 3 & 31 & 25 & 26 & 18 & 0 & 0 & 0 & 0 & 0 & 0 & 100 \\
\hline \multirow[t]{2}{*}{ Panama } & $\begin{array}{l}\text { Original and } \\
\text { scenario } 2\end{array}$ & 40 & 29 & 15 & 7 & 4 & 2 & 1 & 0 & 0 & 0 & 100 \\
\hline & Scenarios 1 and 3 & 100 & 0 & 0 & 0 & 0 & 0 & 0 & 0 & 0 & 0 & 100 \\
\hline \multirow[t]{2}{*}{ Peru } & $\begin{array}{l}\text { Original and } \\
\text { scenario } 2\end{array}$ & 40 & 26 & 16 & 9 & 5 & 2 & 1 & 1 & 0 & 0 & 100 \\
\hline & Scenarios 1 and 3 & 78 & 22 & 0 & 0 & 0 & 0 & 0 & 0 & 0 & 0 & 100 \\
\hline \multirow[t]{2}{*}{ Paraguay } & $\begin{array}{l}\text { Original and } \\
\text { scenario } 2\end{array}$ & 36 & 19 & 17 & 10 & 7 & 8 & 2 & 1 & 0 & 0 & 100 \\
\hline & Scenarios 1 and 3 & 100 & 0 & 0 & 0 & 0 & 0 & 0 & 0 & 0 & 0 & 100 \\
\hline \multirow[t]{2}{*}{ Uruguay } & $\begin{array}{l}\text { Original and } \\
\text { scenario } 2\end{array}$ & 34 & 26 & 18 & 10 & 6 & 3 & 2 & 1 & 0 & 0 & 100 \\
\hline & Scenarios 1 and 3 & 42 & 40 & 18 & 0 & 0 & 0 & 0 & 0 & 0 & 0 & 100 \\
\hline
\end{tabular}

Source: Authors' compilation based on household surveys.

Significant increases in coverage in the first decile are found under perfect targeting (scenarios 1 and 3) especially in Costa Rica, Ecuador, Panama, and Peru (Table 7). However, under this assumption, coverage in Chile and Paraguay does not reach 50\% of the population in the first 
deciles, showing that even if they were totally efficiently assigned, the budgets allocated to transfer programs in these countries would be insufficient to achieve universal coverage in the lowest part of the income distribution.

Table 7: Coverage of CT programs by income decile under different scenarios

\begin{tabular}{|c|c|c|c|c|c|c|c|c|c|c|c|c|}
\hline & & D1 & D2 & D3 & D4 & D5 & D6 & D7 & D8 & D9 & $\mathrm{D} 10$ & Total \\
\hline \multirow[t]{2}{*}{ Bolivia } & $\begin{array}{l}\text { Original and } \\
\text { scenario } 2\end{array}$ & 76 & 64 & 63 & 64 & 58 & 51 & 46 & 39 & 32 & 20 & 51 \\
\hline & Scenarios 1 and 3 & 79 & 70 & 69 & 71 & 67 & 60 & 61 & 6 & 0 & 0 & 48 \\
\hline \multirow[t]{2}{*}{ Chile } & $\begin{array}{l}\text { Original and } \\
\text { scenario } 2\end{array}$ & 8 & 6 & 5 & 3 & 3 & 3 & 2 & 1 & 1 & 1 & 3 \\
\hline & Scenarios 1 and 3 & 30 & 0 & 0 & 0 & 0 & 0 & 0 & 0 & 0 & 0 & 3 \\
\hline \multirow[t]{2}{*}{ Costa Rica } & $\begin{array}{l}\text { Original and } \\
\text { scenario } 2\end{array}$ & 18 & 23 & 17 & 14 & 13 & 11 & 5 & 2 & 1 & 0 & 10 \\
\hline & Scenarios 1 and 3 & 66 & 26 & 0 & 0 & 0 & 0 & 0 & 0 & 0 & 0 & 9 \\
\hline \multirow[t]{2}{*}{ Ecuador } & $\begin{array}{l}\text { Original and } \\
\text { scenario } 2\end{array}$ & 55 & 52 & 41 & 32 & 30 & 22 & 15 & 9 & 3 & 1 & 26 \\
\hline & Scenarios 1 and 3 & 84 & 85 & 77 & 54 & 0 & 0 & 0 & 0 & 0 & 0 & 30 \\
\hline \multirow[t]{2}{*}{ Panama } & $\begin{array}{l}\text { Original and } \\
\text { scenario } 2\end{array}$ & 36 & 26 & 14 & 7 & 4 & 2 & 1 & 0 & 0 & 0 & 9 \\
\hline & Scenarios 1 and 3 & 88 & 0 & 0 & 0 & 0 & 0 & 0 & 0 & 0 & 0 & 9 \\
\hline \multirow[t]{2}{*}{ Peru } & $\begin{array}{l}\text { Original and } \\
\text { scenario } 2\end{array}$ & 41 & 27 & 17 & 9 & 5 & 2 & 1 & 1 & 0 & 0 & 10 \\
\hline & Scenarios 1 and 3 & 85 & 24 & 0 & 0 & 0 & 0 & 0 & 0 & 0 & 0 & 11 \\
\hline \multirow[t]{2}{*}{ Paraguay } & $\begin{array}{l}\text { Original and } \\
\text { scenario } 2\end{array}$ & 14 & 7 & 6 & 4 & 3 & 3 & 1 & 1 & 0 & 0 & 4 \\
\hline & Scenarios 1 and 3 & 38 & 0 & 0 & 0 & 0 & 0 & 0 & 0 & 0 & 0 & 4 \\
\hline \multirow[t]{2}{*}{ Uruguay } & $\begin{array}{l}\text { Original and } \\
\text { scenario } 2\end{array}$ & 77 & 59 & 41 & 23 & 13 & 8 & 4 & 2 & 1 & 0 & 23 \\
\hline & Scenarios 1 and 3 & 92 & 87 & 39 & 0 & 0 & 0 & 0 & 0 & 0 & 0 & 22 \\
\hline
\end{tabular}

Source: Authors' compilation based on household surveys.

The alternative program designs imply, in general terms, very modest effects in terms of reduction of poverty among total population compared with the actual designs, with the exception of Ecuador. In fact, gains in terms of poverty decreases due to efficient targeting are around half a point in Costa Rica and Ecuador in scenario 1 (Table 8). When the budget is doubled and perfect targeting is achieved (scenario 3), three countries are able to decrease their poverty incidence by more than 1 point (absolute change) compared with the actual design of the programs (Costa Rica, Ecuador, and Uruguay). Even in this optimistic scenario, the amounts involved are not enough to pull the whole population out of poverty. Higher gains are made under alternative designs in terms of alleviating the intensity of poverty (FGT 1): again Ecuador and Costa Rica, and now Panama (under scenario 3) get the major improvements. A similar result is obtained for the severity of poverty (FGT 2). Results regarding extreme poverty are presented in Appendix Table A4.

Scenarios 1 and 3 imply a considerable increase in the progressivity of transfers, as reflected by the change in the Kakwani index (Figure 6), especially in Chile, Costa Rica, and Paraguay. The Kakwani index corresponding to scenario 2 is equivalent to that of the original transfer (as only the budget of the program is changed). As expected, important increases in progressivity of the programs could be gained via improvements in targeting. 
Table 8: Poverty incidence and changes under different scenarios measured by ECLAC thresholds

\begin{tabular}{|c|c|c|c|c|c|c|c|c|}
\hline & \multicolumn{5}{|c|}{ Poverty incidence } & \multicolumn{3}{|c|}{$\begin{array}{l}\text { Change (with respect to original } \\
\text { program) }\end{array}$} \\
\hline & $\begin{array}{l}\text { Without } \\
\text { transfer }\end{array}$ & $\begin{array}{l}\text { Original } \\
\text { program }\end{array}$ & Scenario 1 & Scenario 2 & Scenario 3 & Scenario 1 & Scenario 2 & Scenario 3 \\
\hline \multicolumn{9}{|l|}{ FGT 0} \\
\hline Bolivia & 36.2 & 36.0 & 36.0 & 35.4 & 35.7 & 0.0 & -0.6 & -0.3 \\
\hline Chile & 7.8 & 7.8 & 7.7 & 7.6 & 7.6 & -0.1 & -0.2 & -0.2 \\
\hline Costa Rica & 18.3 & 17.7 & 17.2 & 16.8 & 16.3 & -0.5 & -0.9 & -1.4 \\
\hline Ecuador & 36.0 & 33.6 & 33.1 & 30.0 & 26.1 & -0.5 & -3.5 & -7.5 \\
\hline Panama & 24.1 & 23.6 & 24.0 & 22.7 & 23.9 & 0.3 & -0.9 & 0.2 \\
\hline Peru & 24.3 & 24.0 & 24.1 & 23.3 & 23.4 & 0.1 & -0.7 & -0.6 \\
\hline Paraguay & 40.7 & 40.5 & 40.6 & 40.0 & 40.6 & 0.0 & -0.5 & 0.0 \\
\hline Uruguay & 6.6 & 5.6 & 5.3 & 4.7 & 4.3 & -0.2 & -0.9 & -1.3 \\
\hline \multicolumn{9}{|l|}{ FGT 1} \\
\hline Bolivia & 15.5 & 15.2 & 14.9 & 14.8 & 14.3 & -0.3 & -0.4 & -0.9 \\
\hline Chile & 2.5 & 2.5 & 2.3 & 2.3 & 2.1 & -0.2 & -0.2 & -0.4 \\
\hline Costa Rica & 7.2 & 6.9 & 6.0 & 6.2 & 5.2 & -0.9 & -0.7 & -1.7 \\
\hline Ecuador & 13.6 & 11.7 & 8.9 & 9.5 & 5.9 & -2.8 & -2.2 & -5.8 \\
\hline Panama & 10.3 & 9.7 & 9.2 & 8.8 & 8.3 & -0.4 & -0.9 & -1.3 \\
\hline Peru & 8.4 & 8.2 & 8.0 & 7.6 & 7.3 & -0.1 & -0.6 & -0.9 \\
\hline Paraguay & 16.7 & 16.5 & 16.3 & 15.9 & 16.0 & -0.3 & -0.6 & -0.6 \\
\hline Uruguay & 1.9 & 1.5 & 1.4 & 1.2 & 1.0 & -0.1 & -0.3 & -0.5 \\
\hline \multicolumn{9}{|l|}{ FGT 2} \\
\hline Bolivia & 9.3 & 9.1 & 8.7 & 8.7 & 8.2 & -0.4 & -0.4 & -0.9 \\
\hline Chile & 1.3 & 1.3 & 1.1 & 1.1 & 0.9 & -0.2 & -0.2 & -0.4 \\
\hline Costa Rica & 4.3 & 4.0 & 3.2 & 3.4 & 2.6 & -0.8 & -0.6 & -1.4 \\
\hline Ecuador & 7.3 & 5.7 & 3.4 & 4.3 & 2.1 & -2.3 & -1.5 & -3.7 \\
\hline Panama & 6.1 & 5.5 & 4.8 & 4.7 & 3.9 & -0.7 & -0.8 & -1.6 \\
\hline Peru & 4.1 & 3.9 & 3.8 & 3.5 & 3.3 & -0.1 & -0.4 & -0.6 \\
\hline Paraguay & 9.4 & 9.2 & 8.8 & 8.6 & 8.3 & -0.5 & -0.6 & -0.9 \\
\hline Uruguay & 0.8 & 0.6 & 0.6 & 0.5 & 0.4 & 0.0 & -0.2 & -0.2 \\
\hline
\end{tabular}

Note: All values are in percentage.

Source: Authors' compilation based on household surveys.

Figure 6: Progressivity of non-contributory CTs under perfect targeting (scenario 1) as per the Kakwani index

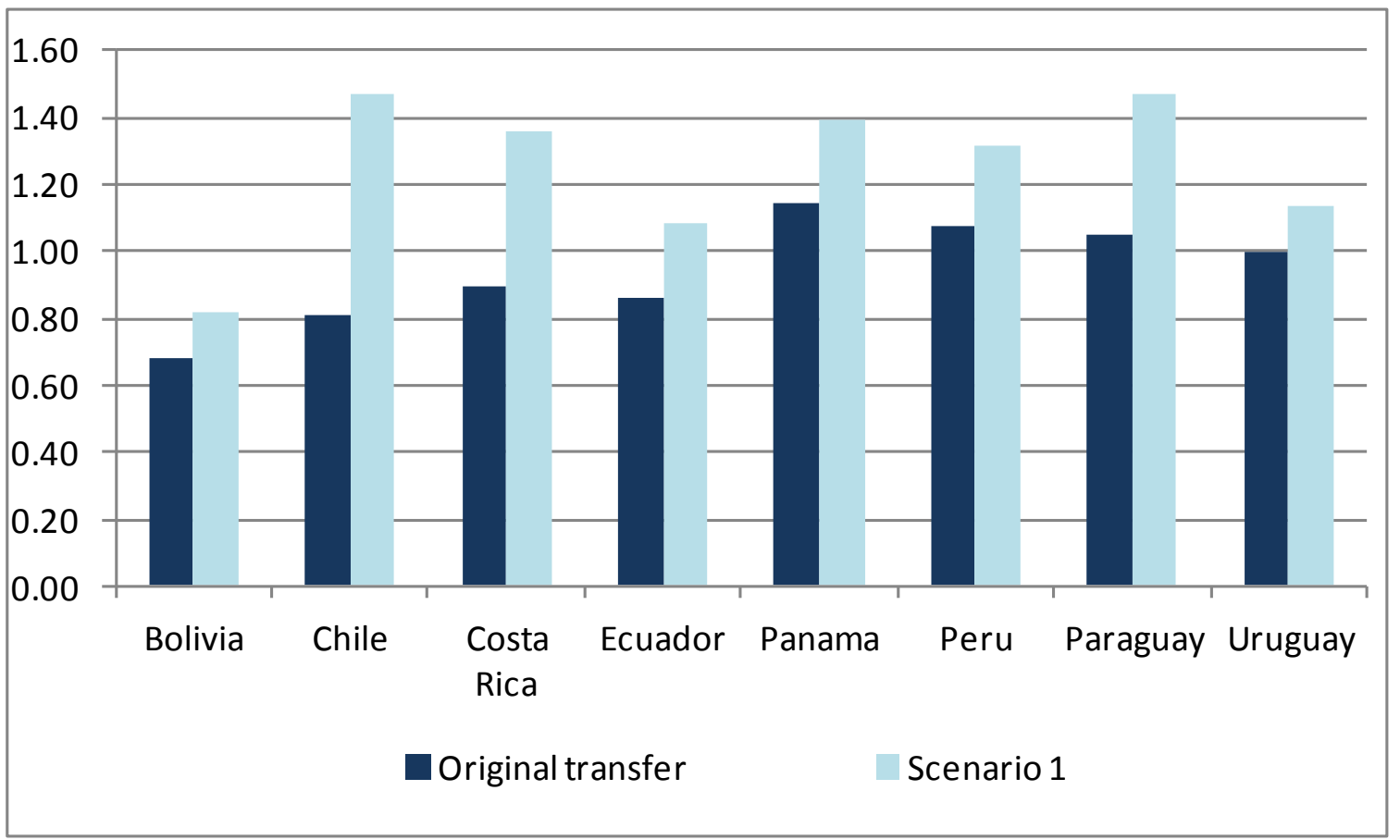

Source: Authors' illustration based on household surveys. 
Improvements in targeting, but especially in the amount of transfers, imply significant decreases in the Gini index, as reflected by the increases in the Reynolds-Smolensky index compared with the baseline without CTs (Figure 7). Major gains are obtained in Ecuador, especially under scenario 3, as the net redistributive impact implies a reduction of 3 Gini points with respect to the baseline without transfers, and almost 2 additional Gini points with respect to the redistribution of the original program. The effects are also significant for Uruguay under scenarios 2 and 3: if the budget of these CTs was doubled, the Gini coefficient could be reduced by 1.5 points (with respect to the baseline without transfers); the gains with respect to the original program are not that dramatic: around half a Gini point. For the other countries, as discussed above, the redistributive impact of CTs is limited because of the amount involved; in those cases, even the duplication of the budget of CTs allows limited redistributive effects. In all cases, the improvement in targeting implied by scenario 1, despite indicating important increases in progressivity (see Figure 6), does not imply a significant redistributive effect compared with the original program design.

Figure 7: Reynolds-Smolensky index under different scenarios

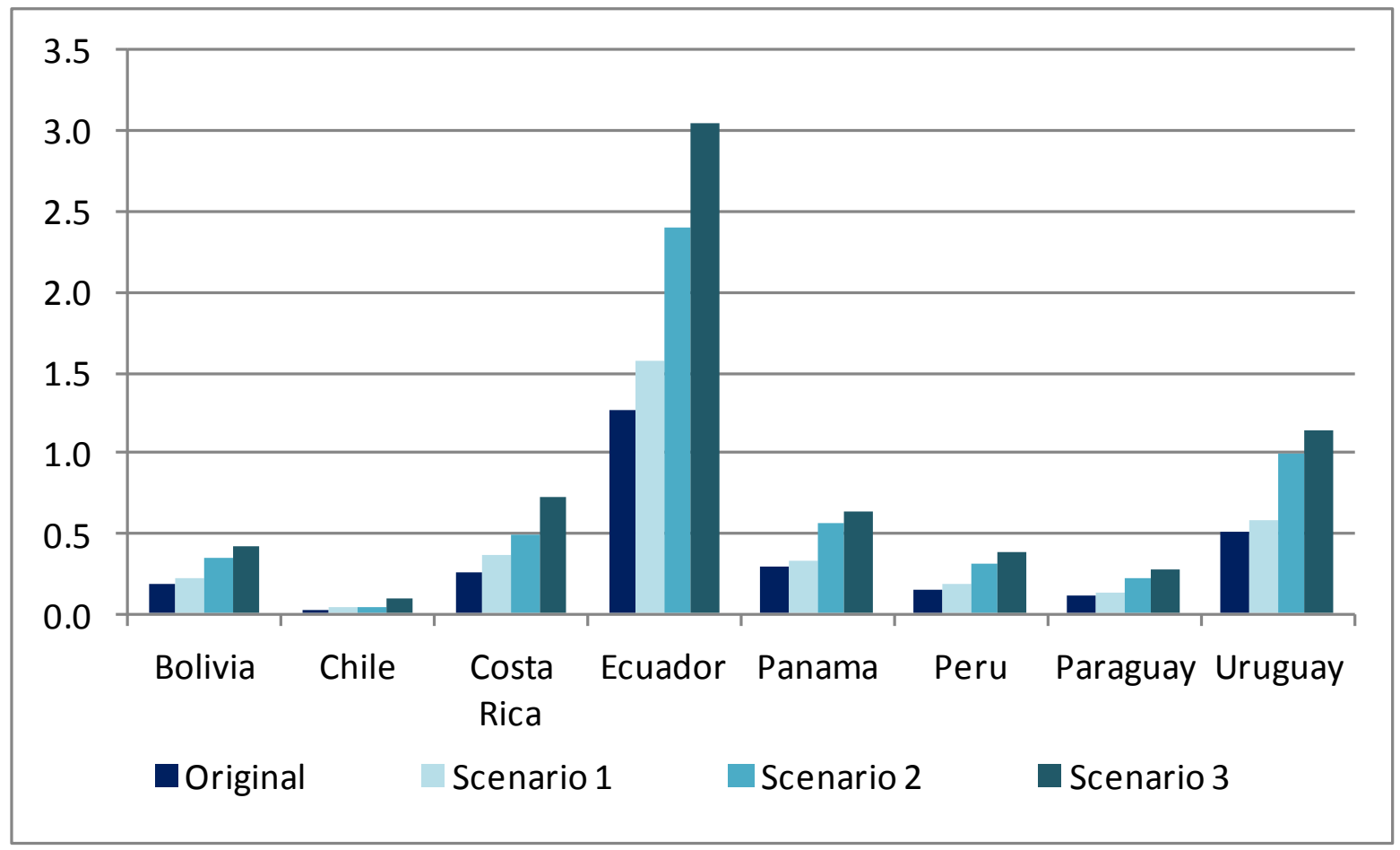

Source: Authors' illustration based on household surveys.

\section{Conclusion}

CTs directed to households with children provide a reliable source of income, covering a significant proportion of the population in Latin America. Although these programs have been considered, in general, as a 'unique model' in the literature, the comparative analysis presented in this article illustrates the important variations among them. According to household survey data, coverage ranges from 3\% in Chile to $>50 \%$ in Bolivia. In the first decile of population, coverage is $8 \%$ in Chile but reaches $76 \%$ in Bolivia and $77 \%$ in Uruguay. These CTs represent a significant portion of household resources in the bottom of the distribution, again with important variations among the cases considered (from $8 \%$ to $30 \%$ of total income in the first decile). Undoubtedly, these transfers help to improve living conditions and beneficiary households are less poor, but 
their effects in terms of poverty eradication or inequality reduction in the cases considered in this paper are limited, mainly because of the amount of resources involved. Expansions in the coverage of the programs have not implied significant increases in budgets. Resources are far from being set at a level sufficient to bring households up to the poverty line, and even with a very optimistic scenario of perfect targeting and doubling of resources poverty rates remain almost unchanged and income redistribution is quite modest. In the cases considered in this paper, CTs seem to have taken a reduced fiscal space to improve people's living conditions and, according to available impact evaluations, to obtain favorable results in different dimensions. Given the magnitude of prevailing poverty gaps in the region, the resources needed to eradicate current poverty or significantly redistribute income would be significantly higher, and beneficiary households remain largely vulnerable despite the transfers.

\section{References}

Alzúa, M. L., Cruces, G., \& Ripani, L. (2010). "Welfare programs and labor supply in developing countries. Experimental evidence from Latin America." CEDLAS Working Paper 95. La Plata: CEDLAS.

Baird, S., McIntosh, C., \& Özler, B. (2011). "Cash or condition? Evidence from a cash transfer experiment.” The Quarterly Journal of Economics, 126(4): 1709-1753.

Barrientos, A., \& Hulme, D. (2008). "Social protection for the poor and poorest in developing countries: Reflections on a quiet revolution.” BWPI Working Paper 31. Manchester: Brooks World Poverty Institute (BWPI).

Bosch, M., \& Manacorda, M. (2012). "Social policies and labor market outcomes in Latin America and the Caribbean: a review of the existing evidence." CEP Occasional Papers No. CEPOP32. London: London School of Economics.

Bouillon, C. P., \& Tejerina, L. R. (2006). "Do we know what works? A systematic review of impact evaluations of social programs in Latin America and the Caribbean." IDB Working Paper 80443. Brazil: Inter-American Development Bank (IDB).

Cecchini, S., \& Madariaga, A. (2011). Programas de transferencias condicionadas: balance de la experiencia reciente en América Latina y el Caribe [Conditional transfer programs: balance of recent experience in Latin America and the Caribbean] [in Spanish]. Santiago de Chile: ECLAC.

Cecchini, S., \& Martínez, R. (2011). Protección social inclusiva en América Latina: una mirada integral, un enfoque de derechos [Inclusive social protection in Latin America: An integral perspective, a rights approach] [in Spanish]. Santiago de Chile: CEPAL/ECLAC.

de Brauw, A., \& Hoddinott, J. (2008). "Is the conditionality necessary in conditional cash transfer programmes? Evidence from Mexico.” One Pager No. 64. Brasilia: UNDP International Poverty Center.

ECLAC (2010). Time for equality: closing gaps, opening trails. Santiago de Chile: ECLAC.

ECLAC (2013). Social Panorama of Latin America. Santiago de Chile: ECLAC.

ECLAC (2015). Inclusive social development: The next generation of policies for overcoming poverty and reducing inequality in Latin America and the Caribbean. Santiago de Chile: ECLAC. 
ECLAC (2016). Non-contributive social programs database. Available at: http://dds.cepal.org/bpsnc/ (accessed 10 November 2016).

Fiszbein, A., \& Schady, N. R. (2009). Conditional cash transfers: Reducing present and future poverty. Washington DC: World Bank.

Gaarder, M. M., Glassman, A., \& Todd, J. E. (2010). "Conditional cash transfers and health: Unpacking the causal chain." Journal of Development Effectiveness, 2(1), 6-50.

Galasso, E. (2006). With their effort and one opportunity: Alleviating extreme poverty in Chile. Washington DC: Development Research Group, World Bank.

Gasparini, L., Cicowiez, M., \& Sosa Escudero, W. (2013). Pobreza y desigualdad en América Latina: conceptos, herramientas y aplicaciones [Poverty and inequality in Latin America: concepts, tools and applications] [in Spanish]. Buenos Aires, Argentina: Editorial Temas.

Gasparini, L., \& Cruces, G. (2010). "Las Asignaciones Universales por hijo: impacto, discusión y alternativas" [Universal assignments for children in Argentina: Impact, discussion and alternatives] [in Spanish]. Económica, 56: 105-146.

Maluccio, J. (2007). "The impact of conditional cash transfers on consumption and investment in Nicaragua." Journal of Development Studies, 46(1): 14-38.

Manley, J., Gitter, S., \& Slavchevska, V. (2013). "How effective are cash transfers at improving nutritional status?” World Development, 48(C), 133-155.

Parker, S., \& Skoufias, E. (2000). "The impact of Progresa on work, leisure, and time allocation." IFPRI Project Paper. Washington DC: International Food Policy Research Institute (IFPRI).

Saavedra, J. E., \& Garcia, S. (2012). "Impacts of conditional cash transfer programs on educational outcomes in developing countries: a meta-analysis." RAND Labor and Population Working Paper Series WR-921-1. Santa Monica, CA: RAND Center for the Study of Aging/RAND Population Research Center, RAND Corporation.

Schady, N., Araujo, M. C., Peña, X., \& López-Calva, L. F. (2008). "Cash transfers, conditions, and school enrollment in Ecuador." Economia, 8(2): 43-77.

Skoufias, E., \& di Maro, V. (2008). "Conditional cash transfers, adult work incentives, and poverty”. Journal of Development Studies, 44(7): 935-960.

Stampini, M., \& Tornarolli, L. (2012). "The growth of conditional cash transfers in Latin America and the Caribbean: Did they go too far?" IZA Policy Paper No. 49, November. Bonn: Institute for the Study of Labor.

Standing, G. (2007). "Conditional cash transfers: Why targeting and conditionalities could fail." One Pager No. 47. Brasilia: UNDP International Poverty Center.

Soares, S., Osorio, R. G., Soares, F. V., Medeiros, M., \& Zepeda, E. (2007). Conditional cash transfers in Brazil, Chile and Mexico: Impacts upon inequality. Brasilia: International Poverty Centre.

Soares, S., Ribas, R. P., \& Soares, F. V. (2009). Focalização e Cobertura do Programa Bolsa Família: qual o significado dos 11 milhões de famílias? [Focus and coverage of the Bolsa Familia Program: What is the significance of the 11 million families?] [in Spanish]. IPEA paper. Brazil: Institute for Applied Economic Research. 


\section{Appendix A: Statistical results}

Table A1: Coverage and budget of selected child transfer programs in Latin America

\begin{tabular}{llll}
\hline Country & Program & Budget (\% GDP) & Year \\
\hline Bolivia & Bono Juancito Pinto & 0.20 & 2012 \\
Chile & Chile Solidario & 0.16 & 2011 \\
Costa Rica & Avancemos & 0.19 & 2014 \\
Ecuador & Bono de Desarrollo Humano & 0.40 & 2014 \\
Panama & Red de Oportunidades & 0.14 & 2011 \\
Paraguay & Tekopora & 0.17 & 2014 \\
Peru & Juntos & 0.20 & 2014 \\
Uruguay & Asignaciones Familiares & 0.46 & 2012 \\
\hline
\end{tabular}

Source: ECLAC (2016).

Table A2: Characteristics of household surveys

\begin{tabular}{lllll}
\hline Country & Year & Coverage & Number of households & Number of people \\
\hline Bolivia & 2011 & National & 8,851 & 33,821 \\
Chile & 2013 & National & 66,725 & 218,491 \\
Costa Rica & 2013 & National & 11,219 & 38,779 \\
Ecuador & 2013 & National & 21,303 & 81,386 \\
Panama & 2011 & National & 12,379 & 46,612 \\
Paraguay & 2013 & National & 5,424 & 21,207 \\
Peru & 2013 & National & 30,453 & 117,731 \\
Uruguay & 2013 & National & 46,622 & 127,925 \\
\hline
\end{tabular}

Source: Authors' compilation based on household surveys.

Table A3: Direct effect of cash transfers (CTs) on poverty (c.2013)

\begin{tabular}{|c|c|c|c|c|c|c|}
\hline & $\begin{array}{l}\text { FGT } 0 \text { (with } \\
\text { CCTs) }\end{array}$ & $\begin{array}{l}\text { FGT } 0 \text { (without } \\
\text { CCTs) }\end{array}$ & $\begin{array}{l}\text { FGT } 1 \text { (with } \\
\text { CCTs) }\end{array}$ & $\begin{array}{l}\text { FGT } 1 \text { (without } \\
\text { CCTs) }\end{array}$ & $\begin{array}{l}\text { FGT } 2 \text { (with } \\
\text { CCTs) }\end{array}$ & $\begin{array}{l}\text { FGT } 2 \text { (without } \\
\text { CCTs) }\end{array}$ \\
\hline Bolivia & $16.20 \%$ & $16.51 \%$ & $7.30 \%$ & $7.54 \%$ & $4.51 \%$ & $4.74 \%$ \\
\hline Chile & $2.28 \%$ & $2.30 \%$ & $0.97 \%$ & $0.99 \%$ & $0.63 \%$ & $0.64 \%$ \\
\hline Costa Rica & $6.38 \%$ & $6.77 \%$ & $2.75 \%$ & $2.99 \%$ & $1.74 \%$ & $1.92 \%$ \\
\hline Ecuador & $11.99 \%$ & $14.83 \%$ & $3.72 \%$ & $5.30 \%$ & $1.86 \%$ & $2.91 \%$ \\
\hline Panama & $11.40 \%$ & $12.21 \%$ & $4.38 \%$ & $5.05 \%$ & $2.39 \%$ & $2.94 \%$ \\
\hline Paraguay & $9.47 \%$ & $9.67 \%$ & $3.62 \%$ & $3.81 \%$ & $2.17 \%$ & $2.30 \%$ \\
\hline Peru & $9.46 \%$ & $9.78 \%$ & $3.04 \%$ & $3.28 \%$ & $1.38 \%$ & $1.53 \%$ \\
\hline Uruguay & $0.33 \%$ & $0.66 \%$ & $0.09 \%$ & $0.17 \%$ & $0.04 \%$ & $0.08 \%$ \\
\hline
\end{tabular}

Notes: Poverty lines are defined as the threshold of US $\$ 3.10$ using 2011 prices at PPP. All values are percentage population (World Bank poverty line).

Source: Authors' compilation based on household surveys. 
Table A4: Extreme poverty incidence and changes under different scenarios measured by ECLAC thresholds

\begin{tabular}{|c|c|c|c|c|c|c|c|c|}
\hline & \multicolumn{5}{|c|}{ Extreme poverty incidence } & \multicolumn{3}{|c|}{$\begin{array}{l}\text { Change (with respect to original } \\
\text { program) }\end{array}$} \\
\hline & $\begin{array}{l}\text { Without } \\
\text { transfer }\end{array}$ & $\begin{array}{l}\text { Original } \\
\text { program }\end{array}$ & Scenario 1 & Scenario 2 & Scenario 3 & Scenario 1 & Scenario 2 & Scenario 3 \\
\hline \multicolumn{9}{|l|}{ FGT 0} \\
\hline Bolivia & 18.7 & 18.4 & 18.2 & 18.1 & 18.0 & -0.1 & -0.3 & -0.4 \\
\hline Chile & 2.5 & 2.5 & 2.1 & 2.5 & 1.9 & -0.4 & 0.0 & -0.6 \\
\hline Costa Rica & 7.6 & 7.2 & 6.2 & 6.9 & 5.1 & -1.0 & -0.3 & -2.1 \\
\hline Ecuador & 14.9 & 12.0 & 10.9 & 9.5 & 7.6 & -1.1 & -2.5 & -4.4 \\
\hline Panama & 12.1 & 11.4 & 11.1 & 10.5 & 9.1 & -0.4 & -0.9 & -2.3 \\
\hline Peru & 5.1 & 4.7 & 4.4 & 4.3 & 3.7 & -0.3 & -0.4 & -1.0 \\
\hline Paraguay & 19.3 & 19.1 & 19.3 & 19.0 & 19.3 & 0.2 & -0.1 & 0.2 \\
\hline Uruguay & 1.5 & 0.9 & 0.9 & 0.6 & 0.5 & 0.0 & -0.3 & -0.4 \\
\hline \multicolumn{9}{|l|}{ FGT 1} \\
\hline Bolivia & 8.1 & 7.8 & 7.8 & 7.5 & 7.5 & 0.0 & -0.3 & -0.3 \\
\hline Chile & 1.0 & 1.0 & 0.9 & 1.0 & 0.7 & -0.2 & 0.0 & -0.3 \\
\hline Costa Rica & 3.3 & 3.0 & 2.4 & 2.9 & 1.8 & -0.7 & -0.2 & -1.3 \\
\hline Ecuador & 5.2 & 3.7 & 3.3 & 2.8 & 2.0 & -0.4 & -0.9 & -1.6 \\
\hline Panama & 5.0 & 4.3 & 3.6 & 3.8 & 2.5 & -0.7 & -0.5 & -1.8 \\
\hline Peru & 1.5 & 1.3 & 1.1 & 1.2 & 0.9 & -0.2 & -0.1 & -0.4 \\
\hline Paraguay & 7.2 & 7.0 & 6.8 & 6.8 & 6.4 & -0.2 & -0.2 & -0.6 \\
\hline Uruguay & 0.4 & 0.2 & 0.2 & 0.2 & 0.1 & 0.0 & -0.1 & -0.1 \\
\hline \multicolumn{9}{|l|}{ FGT 2} \\
\hline Bolivia & 4.9 & 4.7 & 4.7 & 4.5 & 4.4 & 0.0 & -0.2 & -0.3 \\
\hline Chile & 0.7 & 0.7 & 0.5 & 0.6 & 0.4 & -0.1 & 0.0 & -0.2 \\
\hline Costa Rica & 2.1 & 1.9 & 1.4 & 1.8 & 1.0 & -0.5 & -0.1 & -0.9 \\
\hline Ecuador & 2.8 & 1.8 & 1.5 & 1.3 & 0.9 & -0.3 & -0.4 & -0.9 \\
\hline Panama & 2.9 & 2.3 & 1.8 & 2.0 & 1.2 & -0.5 & -0.3 & -1.2 \\
\hline Peru & 0.6 & 0.5 & 0.4 & 0.5 & 0.3 & -0.1 & -0.1 & -0.2 \\
\hline Paraguay & 4.1 & 3.9 & 3.5 & 3.8 & 3.0 & -0.4 & -0.1 & -0.9 \\
\hline Uruguay & 0.2 & 0.1 & 0.1 & 0.1 & 0.1 & 0.0 & 0.0 & -0.1 \\
\hline
\end{tabular}

Note: All values are in percentage.

Source: Authors' compilation based on household surveys. 
Figure A1: Importance of transfer in income of beneficiary households

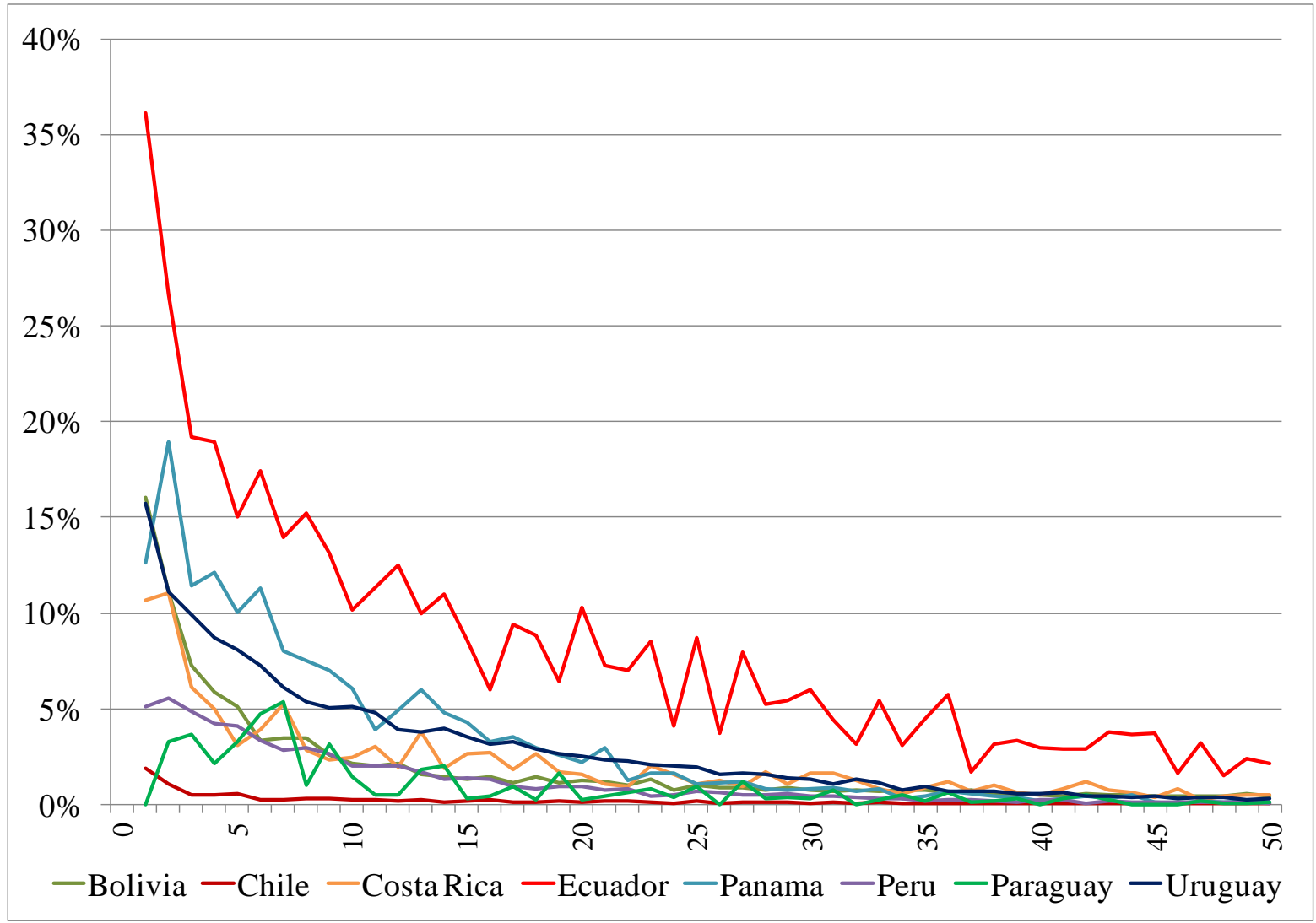

Source: Authors' illustration based on household surveys. 
Figure A2: Per capita transfers as percentage of poverty and extreme poverty line measured by ECLAC thresholds

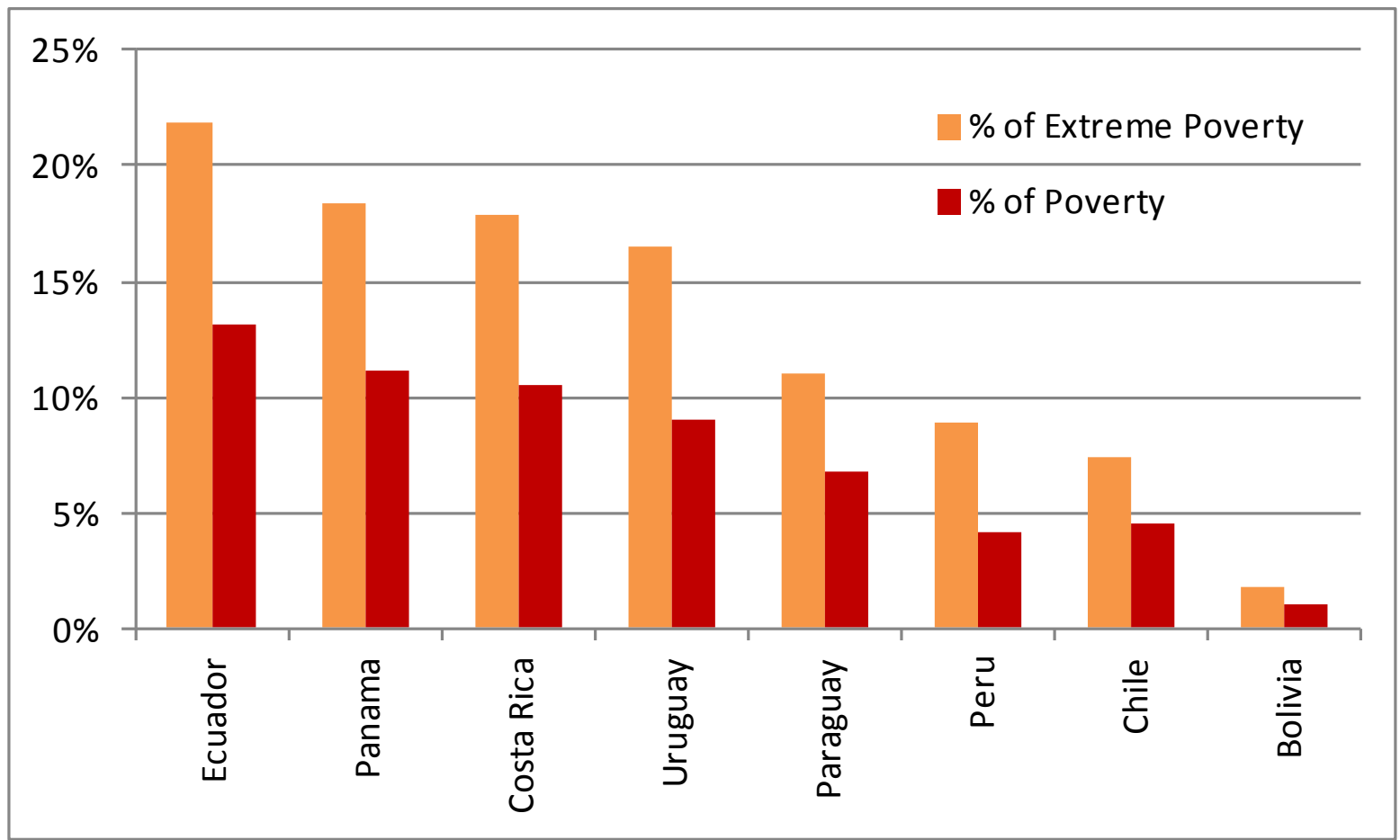

Source: Authors' illustration based on household surveys.

Figure A3: Per capita transfers as percentage of poverty and extreme poverty lines measured by national line (NL) and World Bank (WB) thresholds

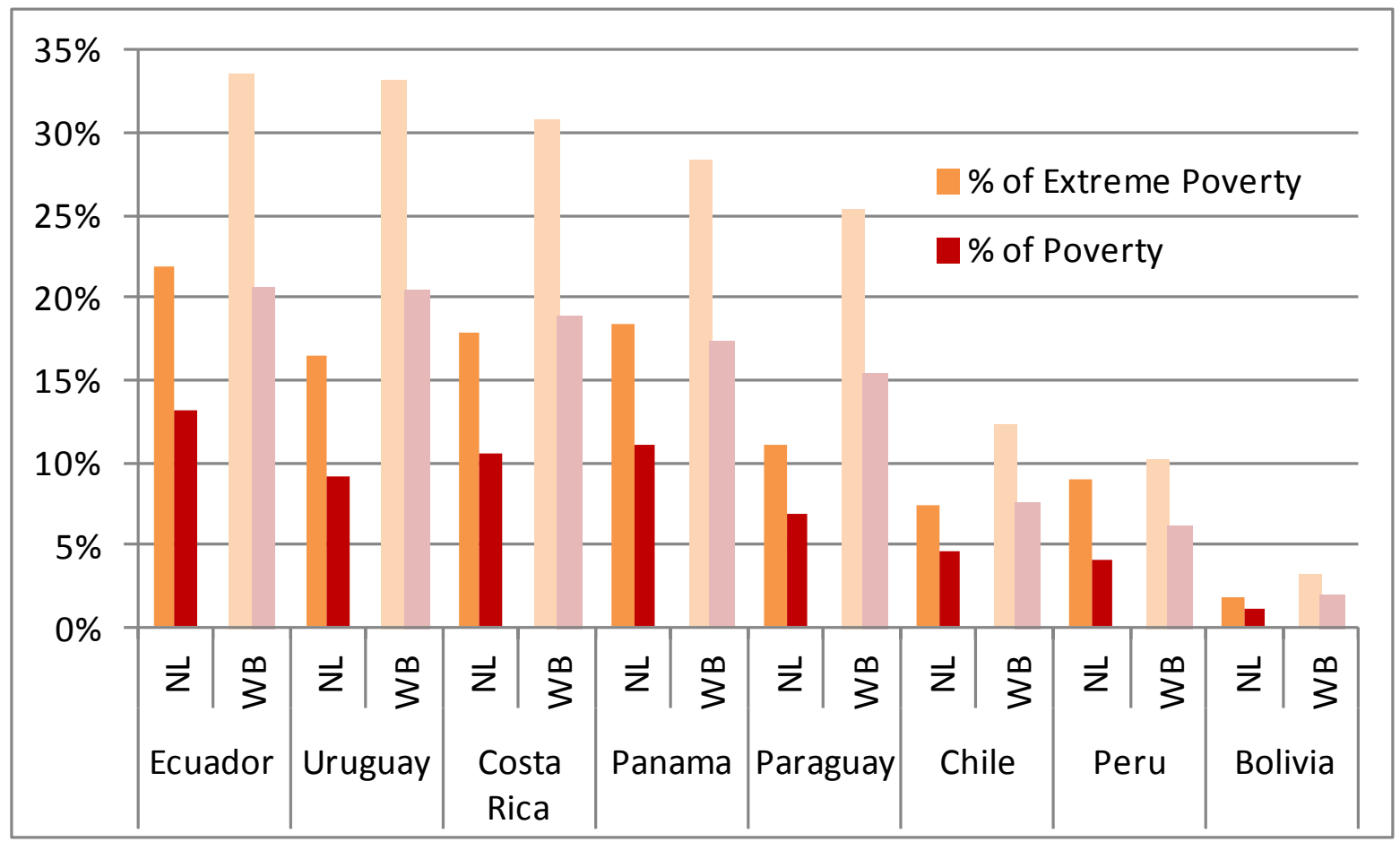

Source: Authors' illustration based on household surveys. 
Figure A4: Absolute (a) and relative (b) change in poverty indicators induced by CTs

(a)

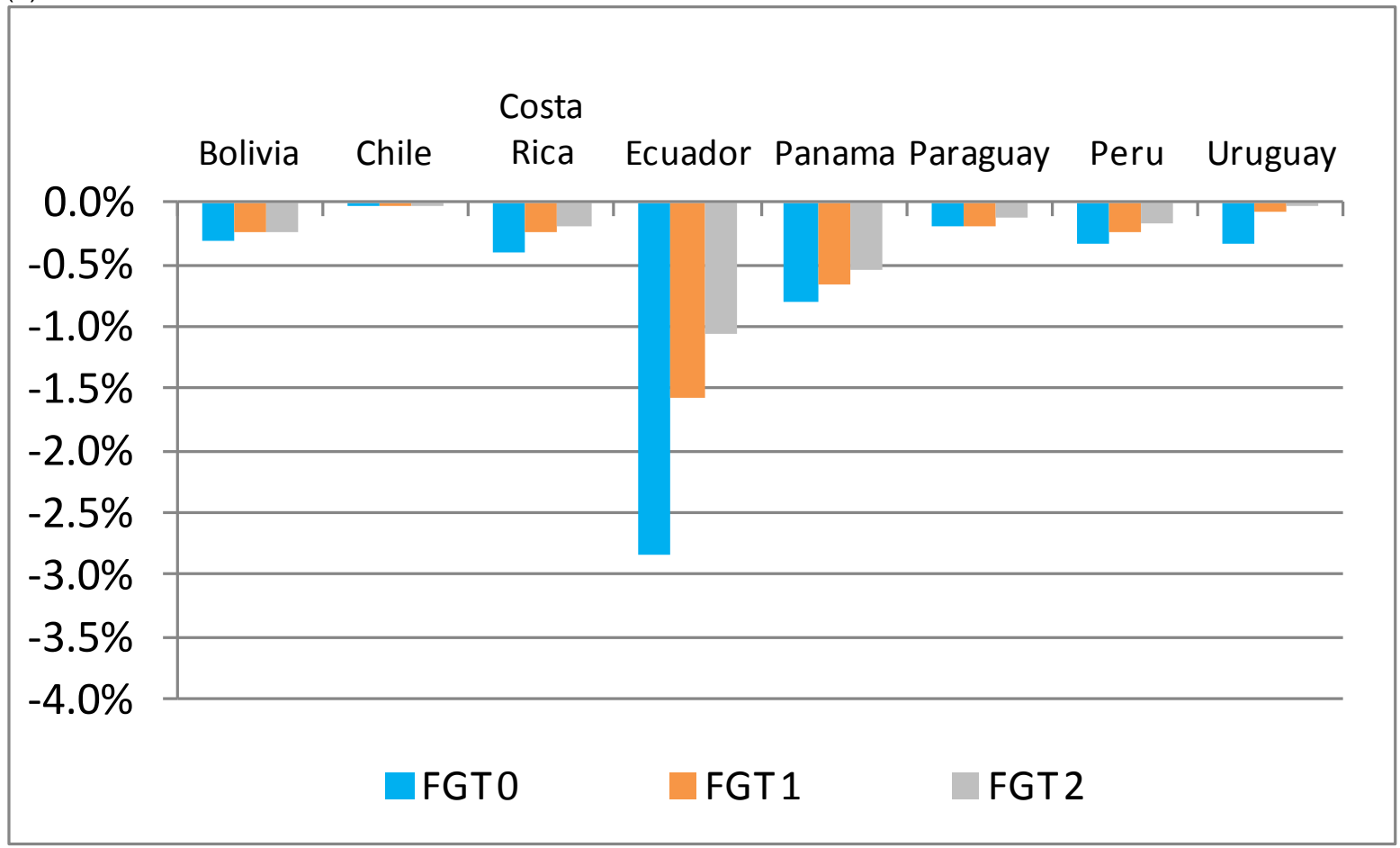

(b)

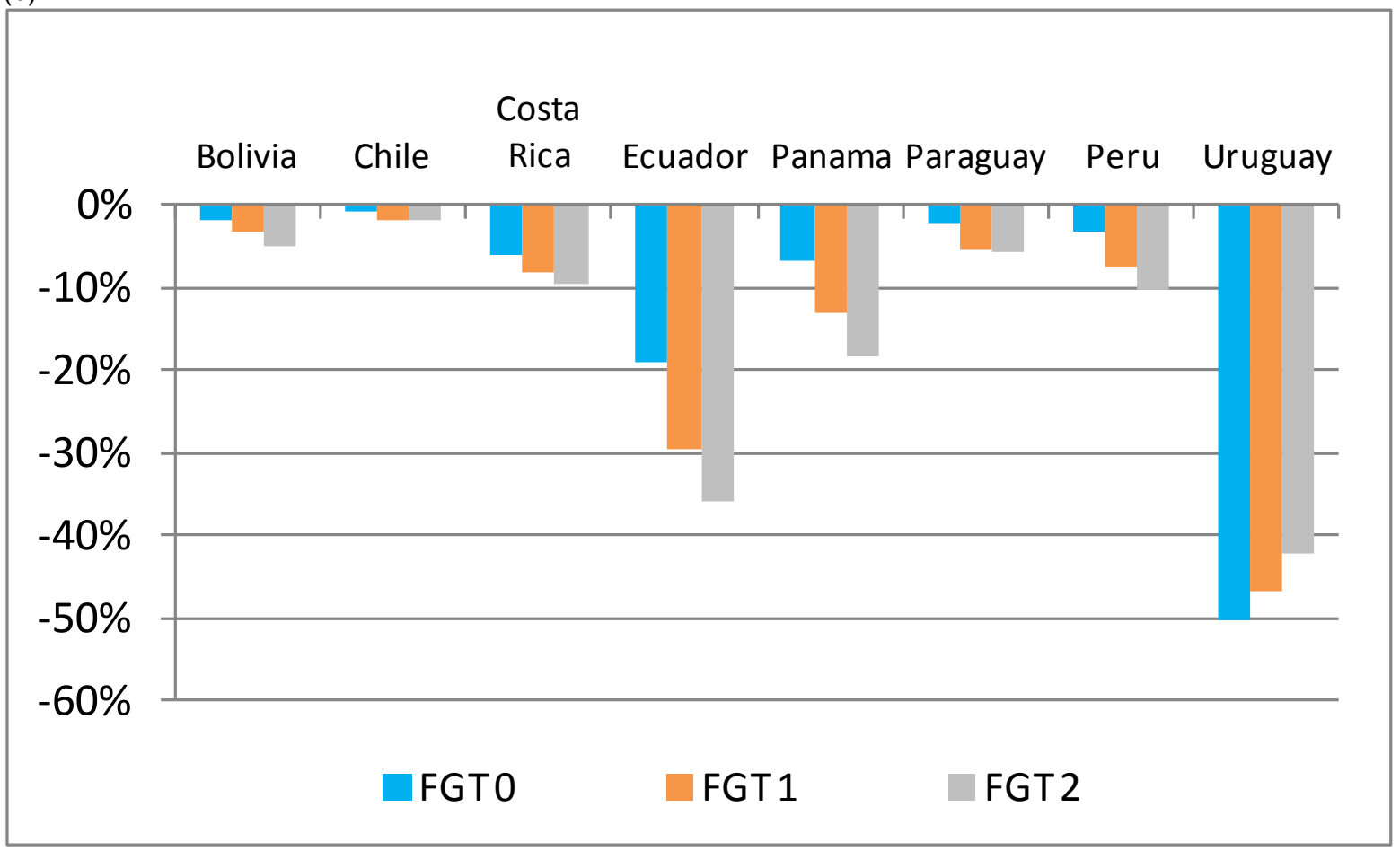

Source: Authors' illustration Based on household surveys. 


\section{Appendix B: Main features of the programs}

\section{Bolivia: Bono Juancito Pinto (BJP)}

BJP was established in Bolivia in 2006. The BJP consists of a cash transfer (CT) to students of public schools, from elementary to secondary level, including students of special education. The transfer of 200 Bolivian pesos (approximately US\$29) is given once a year for each student. In order to receive the BJP, the student must be registered in the Registro Unico de Estudiantes, a database that centralizes information on the students of each school; the student (and the parent) must have their national identification cards and the student must have attended at least $80 \%$ of the school days during that year.

\section{Chile: Chile Solidario}

The Chilean CT system consists of several individual social benefits under the supervision of the government's Ministry of Social Development. The system was created in 2002 by the name of Chile Solidario and subsequently expanded in 2011 introducing a new subsystem, first within and then coexisting with Chile Solidario, called Ingreso Ético Familiar (later renamed as Subsistema Seguridades y Oprortunidades). In 2013, beneficiaries from both subsystems received similar benefits, consisting of a basic CT (Bono de Proteccion Familiar) and benefits bounded to child school assistance, child health control, and youth and women labor participation. Households are selected through a means test. Each household can receive numerous monetary transfers. The Bono de Proteccion Familiar is given monthly to each beneficiary household and amounts to 14,400 Chilean pesos (around US\$30) decreasingly depending on the years participating in the program. The transfers for scholar exceptional achievement are given to children in the top 15\% grades of each schooling year in high school and reaches 50,000 Chilean pesos (around US\$106). Women who work can receive a monetary transfer that complements their wage until reaching a minimum level. Water is subsidized, with households receiving 40,000 Chilean pesos (approximately US\$85) every March; households also receive monthly subsidy in water consumption.

The program varies with regard to the requirements beneficiaries must comply with in order to receive the subsidies. The Bono de Protección Familiar is the first CT given after a family has gone through the phase of psychosocial support. Other monetary transfers, such as the ones related to schooling, health care, and work, have clear requirements.

\section{Costa Rica: Avancemos}

Avancemos was established in Costa Rica in 2006. The beneficiaries are adolescents and young adults between the ages of 12 and 25 years who are currently enrolled in secondary education and fall under the parameters of extreme poverty, established through a means test. The transfer is given monthly and ranges from 15,000 to 50,000 Costa Rican pesos (US\$30-100) depending on the student's grade.

The requirements to receive this subsidy are to remain in school, get annual health check-ups, a signed commitment by the family to stimulate the beneficiary's involvement in school, and falling under the parameters of poverty. 


\section{Ecuador: Bono de Desarrollo Humano (BDH)}

$\mathrm{BDH}$ was created in Ecuador in 2003. The BDH is destined to poor households with children, older adults, or people with disabilities, determined through a means test approach. The transfer is given monthly to each family and amounts to US\$50.

Although the predecessor of $\mathrm{BDH}$ was an unconditional CT, its transformation in 2003 includes new requirements to receive transfers. Households with children below 6 years must take the child to a health check-up at least twice a year, and children between 6 and 16 years must be enrolled in school and must attend at least $90 \%$ of school days.

\section{Panama: Red de Oportunidades}

Red de Oportunidades dates to 2006 in Panama. It consists of a series of actions that seeks to alleviate families living in extreme poverty, identified through a proxy means test. The monetary component consists of a CCT of 50 Panamanian balboas per household (US\$50), given every 2 months. In order to receive CTs, pregnant women must attend health check-ups, children below the age of 5 years must be checked for growth and immunization, children and adolescents must be enrolled in school and maintain an $80 \%$ attendance rate, their parents or tutors must attend school meetings, and one adult must participate in workshops carried out by governmental institutions.

\section{Paraguay: Tekopora}

Tekopora began in 2005 in Paraguay. The program's main feature is a CT to all families that are eligible according to their socioeconomic status and that have the presence of one of the following: children aged below 19 years, pregnant women, adults aged above 65 years, or people with disabilities. The transfer is given every 2 months and the amount varies according to the target group: for children below 19 years and pregnant women, the transfer is of 35,000 Paraguayan guaranies (around US\$9). In addition, every household gets a food support transfer of 80,000 Paraguayan guaranies (around US\$20).

Participating in the program requires beneficiaries to comply with health check-ups and educational attendance. Every member of the participating families must have an identification card and must occasionally participate in the workshops and activities carried out by the program or other public entities, apart from receiving regular visits from community counselors.

\section{Peru: Juntos}

Juntos was established in 2005 in Peru. Its targeting is based on three steps: the first consists of a geographical selection of districts that are considered the most vulnerable; the second consists of a proxy means test subsequently validated by the community members; finally, the household must have children aged below 15 years, pregnant women, or older adults. The eligible family receives a bimonthly CT of 200 Peruvian soles (approximately US\$74). In order to receive Juntos, children must have an $85 \%$ attendance rate and women and young children must regularly visit a doctor. The compliance is supposed to be monitored by the educational and health centers every month and by the program itself, every 2 months. 


\section{Uruguay: Asignaciones Familiares}

Uruguay's conditional CT is called Asignaciones Familiares, consisting of two components: the first dates back to 1943 and is a monthly monetary transfer to formal workers with children in the households attached to their wage; the second is a non-contributory one, established in the early 2000s in order to reach the more vulnerable families. This latter program's beneficiaries are households with children aged below 18 years or people with disabilities whose eligibility is determined through a means test approach. The transfer is given monthly and the amount depends on the number of children, the level of education they are enrolled in, and the number of people with disabilities in the household. Thus, the transfer families can receive ranges from 1,010 to 6,950 Uruguayan pesos (US\$50-350). The requirements on receiving the noncontributory component of Asignaciones Familiares include school assistance and regular medical check-ups. 


\section{Appendix C: Identification of beneficiaries and amounts of transfers}

Some of the transfer programs analyzed consist of several components. The components considered in this study refer to those targeted to households with children. In that sense, it is worth pointing out that we did not consider transfers provided to households with older adults and/or disabled people, which in some countries are integrated with the ones targeted to children in the same program. The latter is the case for Ecuador, Paraguay, and Peru. It is important to note that we also omitted the consideration of transfers attached to particular consumptions (in the form of subsidies) and linked exceptional achievements, which is particularly relevant in the case of Chile.

Components included for the quantification of beneficiaries and amounts of transfers are:

- Bolivia: Unique transfer of Bono Juancito Pintos.

- Chile: Bono de Proteccion Familiar.

- Costa Rica: Unique transfer of Avancemos.

- Ecuador: Unique transfer of Bono de Desarrollo Humano; we excluded transfers exclusively targeted to households with older adults and/or disabled people.

- Panama: Unique transfer of Red de Oportunidades.

- Paraguay: Monetary transfer of Tekopora; we excluded transfers exclusively targeted to households with older adults and/or disabled people.

- Peru: Unique transfer of Juntos; we excluded transfers exclusively targeted to households with older adults.

- Uruguay: Transfers of Asignaciones Familiares, both contributive and non-contributive.

In the cases of Bolivia, Costa Rica, Ecuador, Peru, and Uruguay we imputed the amount perceived due to transfers, as data only registered the beneficiaries but not the cash perceived. In all cases, the imputation was done following rules of each program as stated in ECLAC (2016). 